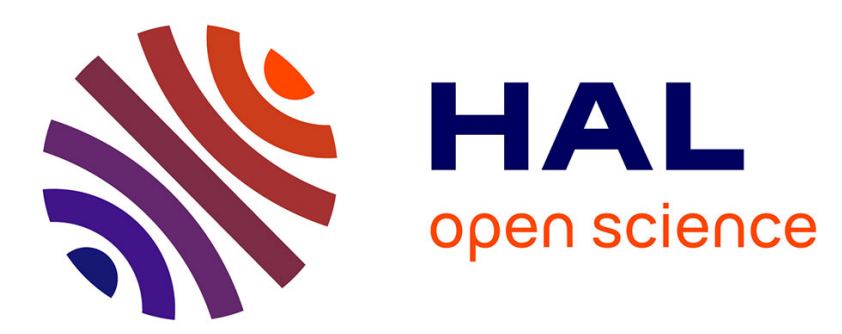

\title{
From the German-speaking point of view: Unholy Empire, Balkanism, and the culture circle particularism of Albanian studies
}

Albert Doja

\section{- To cite this version:}

Albert Doja. From the German-speaking point of view: Unholy Empire, Balkanism, and the culture circle particularism of Albanian studies. Critique of Anthropology, 2014, 34 (3), pp.290-326. 10.1177/0308275X14531834 . halshs-01133422

\author{
HAL Id: halshs-01133422 \\ https://shs.hal.science/halshs-01133422
}

Submitted on 19 Mar 2015

HAL is a multi-disciplinary open access archive for the deposit and dissemination of scientific research documents, whether they are published or not. The documents may come from teaching and research institutions in France or abroad, or from public or private research centers.
L'archive ouverte pluridisciplinaire HAL, est destinée au dépôt et à la diffusion de documents scientifiques de niveau recherche, publiés ou non, émanant des établissements d'enseignement et de recherche français ou étrangers, des laboratoires publics ou privés. 


\section{From the}

\section{German-speaking point of view: Unholy Empire, Balkanism, and the culture circle particularism of Albanian studies}

\author{
Albert Doja \\ University of Lille, France
}

Critique of Anthropology 2014, Vol. 34(3) 290-326

(C) The Author(s) 2014

Reprints and permissions: sagepub.co.uk/journalsPermissions.nav DOI: $10.1177 / 0308275 \times 14531834$ coa.sagepub.com ९SAGE

\begin{abstract}
In this paper, I aim to contribute to the debate about hegemonic relations between the West European "core" and southeast European "margins," by showing the links between mutually challenged and engendered quasi-anthropological traditions in the totalitarian projects of nation-building and empire-building. New aspects of a continuous resonance will be addressed between a politically instrumentalized Albanian tradition of "folk" or people's culture studies (kultura popullore) and a German-speaking tradition of Volks- and Völkerkunde grounded in Herderean Romanticism and the imperial ambitions of the nineteenth century. In the course of discussion the successive German traditions of National-Socialist Volkskunde and Communist East German Ethnographie, until the revised tradition of Europäische Ethnologie in the 1990s, are shown to operate from a historicist tradition rather than from a critical tradition as a reflexive successor to former Volkskunde. In the course of this discussion, I will pay particular attention to contextualizing the historical and current production of knowledge by the German and Austrian "West" on a Balkan and Albanian culture, which is reduced to its archaic or pre-modern "traditions" and its specific or antiquated "mentalities."
\end{abstract}

\title{
Keywords
}

Descriptivism, exoticism, nationalism, folklorism, Volkskunde, culture circle theory, Albanologie, Albanian studies, socialism, postsocialism, imperialism, Balkanism, Kulturpolitik, Ostpolitik, Germany, Austria, Albania, southeast Europe

\section{Corresponding author:}

Albert Doja, Institute of Sociology \& Anthropology, Clersé UMR CNRS 8019, University of Lille, France. Email: albert.doja@univ-lilleI.fr 


\section{Introduction}

This paper stems from a question on the mainstream and dissident scientific networks between the Balkans and Germany, formulated with an invitation to give a presentation at a conference sponsored by Deutsche Forschungsgesellschaft in September 2012 at Humboldt University in Berlin. ${ }^{1}$ The focus on the history of institutions, the careers of particular individuals, intellectual biographies, trajectories and followers is crucial to understanding scholarly networks between German-speaking areas and Albania as between mainstream and local traditions. The number of solid studies that address the ideological foundations and political practices of scholarly production in and on the Balkans is also in steady rise at least since the 1990s. The critical handling of ethnographic-historical sources and the actual contributions of practitioners of the discipline produced within certain methodological and theoretical frameworks involving German-speaking intellectual influence may also be of equal importance in assessing the development of Albanian studies and anthropology.

The German tradition or paradigm of Volkskunde could be forwarded as an illustrative case of the politics of knowledge in the area of Albanian studies, especially works related to folkloric tradition, anthropology, history, philology, archaeology and related disciplines. Surely, this does not mean that a "German-speaking point of view" in the development of Albanian studies can be reduced to a simple metaphorical expression for understanding "culture" in terms of Volksgeist. If the discussion is aimed at contributing to the debate about hegemonic relations between the West European "core" and Southeast European "margins," the various influences of German-speaking scholarship on Albanian studies cannot be homogenized to disregard their differences and historical peculiarities over a century of scholarship. It is necessary indeed to contextualize the disguised "supra-colonial", "crypto-colonial" or "self-colonizing" conditions (Pandolfi, 2000; Herzfeld, 2002; Kiossev, 2011), some new words for the old concepts of internal colonialism, post-colonialism or neocolonialism, which I also showed elsewhere to have permeated the public life in Albania and Kosova (Doja, 2001). Such a contextualization is crucial in the historical as well as in the current production of any knowledge at a given time, in a given place, and for some given purpose. This can be highly suggestive in understanding how Western colonialism maintained and continues to maintain a surprising degree of cultural and political influence far beyond its official spheres of power.

The anthropological traditions in Germany, Austria, and the German-speaking parts of Switzerland cannot be treated independently before the 1960s. The Austrian academia had always been an integral part of the German-speaking scientific world and mutual exchanges of scientific and academic personnel between German, Austrian, and Swiss institutions were frequent. Most leading members of the early- to mid-twentieth-century Vienna school of anthropology were German priests, most prominent German anthropologists were Austrian by birth and by academic education, and key figures in twentieth-century Swiss anthropology were also German or Austrian citizens. The aim of this paper was not, however, to offer a contextualized historical view and comparison between the different intellectual 
productions of German-speaking scholarship and Albanian studies, neither to exhaustively treat each of them on their own. Accordingly, the contemporary production in German or in Albanian (and even by German or Albanian authors publishing in English) cannot be reviewed in its entirety.

Some recent works do much to illuminate the disciplinary histories throughout eastern Europe and the Balkans. Especially, a series of conferences revealed that ideology, either nationalist or communist, has played a major role in the formation and development of ethnography, ethnology, folkloristics, and social anthropology in many Balkan countries. A conference organized by the International Association for Southeast Anthropology in Bankja (Bulgaria) in August 1996 focused on "Ideology in Balkan Anthropology,", whereas a series of conferences organized by the Max Planck Institute for Social Anthropology in Halle/Saale (Germany) focused on the rise of anthropology during the socialist era in people's democracies, such as in August 2003 limited to East-Central Europe (Hann et al., 2005), in June 2006 to South-East Europe (Mihailescu et al., 2008), and in March 2011 to the Balkan "margins of Europe" (Hann and Bošković, 2014). The contributions outline how the intellectual endeavors were affected by formally internationalist but in substance deeply national versions of socialism. Scholars were able by and large to nurture and sustain their special relationship to the nation under dramatically altered conditions, reacting more or less skilfully to fluctuating political pressures, and eventually finding a secure niche for themselves in national communism.

Depicting the different methodologies and approaches that distinguish academic traditions in different societies is certainly useful. It is perhaps even more important and at once more problematic to reveal the different political, social, ideological, and cultural implications of various traditions. However, I am not pitted between a historical strand in its own right and another concerned with the present uses of the past, or to use George Stocking's opposition between "historicist" and "presentist" analyses (Stocking, 1965). My concern is rather to offer a revised account of the history of Albanian studies as practiced by both German-speaking and native scholars and viewed from an insider/ outsider perspective. Rather than leaning towards either presentism or historicism, the aim is to concentrate on the intellectual history of ideas, methods, and contributions, through the mixing of historicism with a degree of a more frankly presentism in which the "German-speaking point of view" is reexamined for its contemporary uses.

The critical review of the scholarly production on Albania and the Balkans is aimed at offering a reconstruction of the shifting ideological foundations of the folkloric-ethnographic production in Albania and the region. The focus is therefore on the cultural particularism and cultural determinism in the writings of German-speaking scholars on the Balkans, especially on Albania and the Albanians, and on the reaction of Albanian scholars in adopting and integrating the same culturalist patterns of the German-speaking intellectual influence. Taken together, a critical reassessment of these strands may contribute to present debates within anthropology. If anthropology is to emerge and persist as a viable field, in Albania as elsewhere, it needs to attend more carefully to its own social reproduction. The task is therefore not to simply summarize previous and established 
insights and opinions, but rather to question those previously established opinions that today seem to be one-sided. Ultimately, we need to consider how to engage constructively with the past in ways that may develop a vision for a renewed anthropology within Albanian studies from the perspective of those presentist, critical, and internationally oriented positions that we need to strengthen and promote today.

\section{Kulturpolitik and the foundation of Albanologie}

Beginning in the 1830s and accelerating after the emergence of the German nationstate in 1871, nationalism increasingly was instrumentalized as a force serving dominant Prussian interests, while German Volkskunde was acquiring socio-political significance in the quest to bind together the country's previously fragmented regions. After the historiographic and historicist school of writing history superseded philosophy to become the dominant force in the Geisteswissenschaften throughout the nineteenth century and thereafter, Volkskunde became an integral part of German historicism (Gingrich, 2005). In association with the development of ancient art history and Germany's pronounced "cultural obsession" with the glories of antiquity, and the subsequent establishment of exacting standards of scholarship in allied disciplines under historicist hegemony such as Altertumskunde and comparative philology, German Volkskunde became established as the historicist study of a superior Germanic self. Its practitioners were in charge of proving common archaic origins, the evidence of which was to be found in Volkskultur, thus revealing the Herderian Volksgeist set apart from the study of the Herderian Naturvölker (Stocking, 1996). Similarly, on the formal and institutional level, the academic establishment of German Völkerkunde was caught up with national interests in the context of Prussian emergence as an imperial power with colonial ambitions in Europe (Zimmerman, 2001). While the initial motives were channeled and shaped by various contexts (Penny and Bunzl, 2003), the research projects of its practitioners were strongly embedded in the objectifying exoticism of folkloric museum displays, adventurist reports, and voyeurist exhibitions (Völkerschauen) of an aggressive colonialist newcomer.

Both Völkerkunde and Volkskunde derived from a historicist and museumoriented tradition in which Völkerkunde dealt with the culture history of external others and Volkskunde with the historical others of the national cultural tradition. More than a simple demarcation between them, a complementary division of labor is assumed, both of which having contributed to the construction of "Other," both inside and outside Europe. They did not develop during a time of imperial expansion as ethnology in France and anthropology in Britain, but during a time of imperial aspiration. If in the national context the historicist model for Volkskunde led to Herder's notion of Volksgeist, in the new colonial context the natural science model for Völkerkunde led to a continued revitalization of Herder's notion of Naturvölker, natural or primitive peoples with little or no culture and no history, who thus could reveal the true nature of humans. The intensive investigations carried out alongside with scholars from other German-speaking countries favored 
a tripartite model of history and conceived local societies as Naturvölker "primitive peoples," Stammeskulturen "tribal cultures" and Volkskulturen "people's cultures". Based on the important precursors of a well-established philological and philosophical tradition, this model was informed by a more or less explicit distinction between what were considered primitive and illiterate, Oriental and literate, and modern European cultures and languages (Gingrich, 2005: 69). A hierarchy in terms of developmental potential thus was explicitly introduced in this tripartite classification of history and society, which further contributed to universal typologies of hierarchical "human species" (menschliche Arten). In Germany, Austria, and many parts of East Central Europe, a notion of origins thus developed, according to which humanity's "limited inventiveness" or "mental poverty" (Ideenarmut) was compelled to improve under the influence diffused from a few focal "civilizing circles" (Kulturkreise) of some given "civilized peoples" (Kulturvölker). German diffusionism thus became a genius-centered, speculative history of hierarchical cultural distributions.

In both branches of Völkerkunde and Volkskunde, German scholarship was a formidable player in the international scene, launching some of the largest anthropological expeditions, having a powerful presence at international conferences and founding a number of internationally recognized periodicals (Penny and Bunzl, 2003). Heavily state-subsidized organizations and institutions as the support of "disinterested" German philanthropy abroad were meant to highlight the achievements of German scholarship. In reality, Kulturpolitik was a state policy intended to enhance German national prestige that yielded to the commanding presence of a high antiquity created in the crucible of late eighteenth-century Aryanism. Although the German philologists and art historians who generated the Aryanist model of German culture may have not explicit racist and colonialist views, they were doing the ideological work of the supremacist project of German hegemony leading to the cultural eugenics of a Nazi "race science" (Rassenkunde). Actually, German Kulturpolitik disguised imperialist aspirations that occasionally were made explicit. In 1902, the German consul to Constantinople unequivocally qualified German archaeological policy throughout the lands of the Ottoman Empire as a gradual spiritual conquest (geistige Eroberung) of the Orient:

The interim intellectual goals already pursued, or to be pursued by our schools, our doctors, and our archaeologists could very well become, in the course of time, the crystallization point onto which German economic and colonizing undertakings are grafted. The economic will follow the intellectual conquest as a natural result, and then these two diffused phases will naturally be followed by the third stage, that of political exploitation (Verwertung) and consolidation of the cultural values we have created. (quoted by Marchand in Stocking, 1996: 318)

The colonial contributions by German and Austrian scholars may have remained fairly limited in substance and relatively heterogeneous as to their purpose and direction (Penny and Bunzl, 2003: 23-27). However, virtually all 
representatives of Völkerkunde profited from and worked for colonial interests until 1918. They continued during the First World War to be actively at the service of colonialism and the imperial armies in both German and Austro-Hungarian empires, more explicitly and more directly than did their counterparts in France and Britain (Johler et al., 2010). Many of them carried out research documentation especially among prisoners of war and in the Balkans. It has been argued that such a practice constituted one of the most decisive fields by which linguistic and ethnographic inquiries were brought together with racial studies much more closely than had been the case before. In addition, its far-reaching influence helped to refine the scientific and nationalist agendas in Central and South-East Europe (Turda, 2013).

The case of Austria-Hungary clearly shows the extent to which the politics of knowledge on the Balkans is informed by imperial interests, even though simplified historiographic equations of Völkerkunde with colonialism and Volkskunde with nationalism do not work as easily in the Austro-Hungarian or Swiss contexts. Being developed in a context quite different from that of Germany, Austrian Völkerkunde went beyond the stereotypes and blind spots of Orientalism, while the link between Volkskunde and nationalism, so typical for the rise of folklore studies in Germany, was not possible for a scientific community aspiring to public acceptance and advancement in political entities that were quite diverse linguistically, religiously, and culturally (Gingrich, 2005). Although ethnicity was a key concept, in the German-speaking parts of Switzerland and the Habsburg lands, it was understood as different from the political concept of nationality and subjection to the confederal or imperial state, while nationalism of any kind was generally dealt with as a subversive, secessionist danger.

As national folklorist movements evolved toward the end of the nineteenth century, Vienna launched a Volkskunde that had to deal with a given cultural diversity of all the peoples of the Monarchy. Specifically in the provincial centers, a diverse spectrum of academic institutions, museums, learned societies, and numerous private initiatives were active in this field. Some of these had a more aesthetic, some a more academic, others yet a more political mission, not without some limited nationalist leanings in the German-speaking parts of the empire and somewhat more explicit nationalism in other, more peripheral parts. The protagonists, and at least a part of their growing support base in the bourgeoisie and aristocracy, were stakeholders in a liberalism supportive of the state. Unlike the subject populations of other empires of the time, such an approach was facilitated by the fact that the empire's various peoples were all found to belong to a common Indo-Germanic race. The "real Volk" of the Empire was conceptualized to be found underneath superficial national and ethnic differences as an underlying universal and primitive substrate. Empathic governance was to capitalize on the cultural diversity of the empire, thus resonating with Herder's vision of humanity as existing in Einheit durch Vielfalt, which was promoted as the essence of the empire's own "unity through diversity." Translated into an implicit academic paradigm, the aesthetic refinement of this liberalism and a kind of fair trade through the consideration of traditional social structures promoted the conjunctive rather than 
disjunctive aspects of culture and the emergence of a less nationalist and more interculturally oriented tradition of people's culture studies.

Yet, intercultural liberalism did not mean egalitarian culture. Culture was a hierarchical concept and the claim for a leading role of German culture was not questioned. Arguably, this would also mean that the evolution of Volkskunde as a discipline in Austria was much more closely related to colonial expansion than its Völkerkunde counterpart. The particular Habsburg brand of imperial expansionist energies were of short distances (Feichtinger et al., 2003), projected into the postOttoman territories in southeastern Europe rather than overseas. In the nineteenthcentury context of the hegemony of Russia in eastern Europe, the displacement of Austro-Hungarian political and economic interests out of Germany and Italy brought the concentration of the foreign policy of the Habsburg Monarchy on the Balkans as the only way to resist Panslavism and Italian imperialism. Thus, a premier "colonial situation" for Austria-Hungary was located in the former Ottoman provinces of Bosnia and Herzegovina occupied in 1878 and finally annexed in 1908. In the last quarter of nineteenth century and early twentieth century, continued weakening of the political and economic position of AustriaHungary in the other Balkan states, which were becoming increasingly independent, induced Austro-Hungarian special interest in Albanian-speaking territory. Austria-Hungary played an important role in the formation of an Albanian independent state in 1912, while Albania was compelled to acquire political independence at the expense of massive economic dependence. The intensification of Austrian-Albanian relations in fields of politics, commerce, culture, and research was intended to secure and strengthen its political, economic, and cultural influence over Albania in the form of an informal imperialism based on structural violence (Gostentschnigg, 1999). This was mainly achieved by means of a Kultusprotektorat over Albanian Catholics within the Ottoman Empire (Deusch, 2009), by means of extensive financial support of educational and cultural activities (Ramadani, 2010), and by means of the development of Volkskunde and other research on Albanian history, language, and culture.

Representing a liminal region between the two approaches of Völkerkunde and Volkskunde, the Balkans became a key field of research for both. Their respective institutions were exploiting every possible way to systematically promote themselves as the future centers for the study and presentation of the Balkans. Austrian scholars of Volkskunde presented more successfully an agenda for continued research into the culture and ethnography of the Balkans that promised the production of knowledge which would be useful for the military, economic, and political interests of Austria-Hungary (Marchetti, 2013). Research and publishing activity of the Austro-Hungarian Volkskunde of the Balkans and Albania experienced a boom that paralleled the political interests of the Habsburg Monarchy in the area in the height of the political and commercial rivalry with Italy and in the course of the First World War with the military occupation and administration of good parts of the region between 1916 and 1918. With an implicit attempt to gain recognition by the state and realize a footing as a university discipline, Austrian 
Volkskunde showed an intensive interest in the studies of the occupied territories in the Balkans, including Albania, and scholarship went hand in hand with collaboration, if not collusion, with military occupation and political administration of these areas.

The Institut für Balkanforschung was founded in 1908 in Sarajevo at the initiative of the Austrian Foreign Ministry to face the Italian concurrence in the exploration of south-east Europe, which must be seen as the expression of the Austrian claim to take over the leading role in Balkan studies, while regular research expeditions were organized by the Austro-Hungarian Academies of Sciences (e.g. Haberlandt, 1917) and a number of scholars were travelling into the Albanian territories to explore the country and the people. The development of these studies aimed at inducing the preference of not only Catholics but also Muslim Albanians for the Habsburg Monarchy over other Powers, as they may appreciate AustroHungary for its interreligious tolerance and its resistance to Panslavism. As the Austro-Hungarian scholarship seemed to boost the strong sense of honor and the national consciousness of Albanians, they had to foster a sense of sympathy and gratitude toward the Habsburg Monarchy, which in turn could give Austrian interests in Albania an advantage over other political and economic competitors, including Italy. In addition, research expeditions in Albania had to provide a clear picture of the cultural, social, economic, and political life, which could be exploited for investment opportunities by the Habsburg Monarchy.

It is in this context that a group of German-speaking writers were mobilized, mostly Austro-Hungarian and Prussian scholars with a strong interest in Albanians and their history, language, and culture. Several of them shaped the founding generation of Albanian studies, or what came to be known as Albanologie in German-speaking jargon. Surely, there was no concrete political programme for an instrumental research, but a generous stimulation of Albanologie and Volkskunde, so that in a more serious situation, namely the First World War, they could be put at the disposal of the Austrian state interests. Indeed, as stated by Gostentschnigg (1999: 244-245), some renowned Austro-Hungarian scholars worked in Albania both for academic research and for the policy of their country, such as the consul Johann Georg von Hahn, the secret agent Franz von Nopcsa, or the politician Ludwig von Thalloczy, while the work of many others was also exploited for political and commercial strategic objectives. Many of these scholars dealt with archaic cultural features of the Albanian society, especially concerning customary behavior and the so-called tribal organization, or the ethnogenesis of Albanians, which included the question of the Illyrian heritage and the extent and results of successive processes of Hellenization, Romanization, Slavicization, and Islamicization of present-day Albanian-inhabited areas (Thalloczy, 1916). It is possible that some of their observations turned out to be wrong or misleading on further research, but their contributions still provide a short expedient for further studies by native scholars in Albania.

The importance of these scholars in the periphery of the imperial center, however few in number, altogether with other adventurers, travelers, traders, soldiers, 
and colonial consuls, can be shown not only on local people, especially the elites, but constantly in their decisive influence over imperialistic processes (Mommsen, 1980). Actually, a related problem with many of the writers of the old generation of Albanian studies is that they consciously or unconsciously promoted the idea that at the beginning of the twentieth century, the "unknown" Albanians were still at the stage of the last "undiscovered" people in the Balkans, so close and yet so far on the southeastern "margins of Europe," to recall a phrase coined in a similar context for neighboring Greece (Herzfeld, 1987). As some of the new generation of German-speaking scholars acknowledge (e.g. Gruber, 1998; Gostentschnigg, 1999; Hemming, 2012; Kaser, 2002; Marchetti, 2013; Promitzer, 2012), it was in particular the Orientalizing and Balkanizing images of old German-speaking writers who selected and reported observations almost exclusively from the northern Albanian regions that singled out certain seemingly "archaic" phenomena which were labelled and reified as "Albanian". They put emphasis on the so-called Albanian "tribes" and their primitive laws, archaic blood revenge, the primitiveness and purity of the indigenous people, Spartan simplicity yet incomparable hospitality, and so on. A special genre of accounts on blood feud developed, which was inspired especially by those Austrian and German travellers whose writings, typical of a travelogue, were primarily aimed not at providing information or conducting scholarly work but sensational discoveries to acquire artificial prestige (Kaser, 2002). According to the intention of one or another of these writers, Albanian "tribesmen" were depicted either as savages and barbarians or as outstanding virile and heroic "sons of the eagle." The impression is always given that people's life was concerned with blood feud and nothing else. Otherwise, a very appealing sentiment of heroism was used, in a definite tendency towards an idealization of Albanians, especially the northern mountaineers, depicting local life and customs in a heroic and glorious light, idealizing patriarchal society and its manly features, bravery, honor, and hospitality.

It is all this that must have boosted an intellectual movement among native scholars. Among them, Shtjefën Gjeçov (1874-1929) was an Albanian Kosovaborn Franciscan priest and freedom fighter, who dedicated himself at the turn of twentieth century to the record of North Albanian traditions and legends and began to publish them from 1913 onwards in the Franciscan journal Hylli $i$ Dritës printed in Shkodra. He travelled to North Albania at practically the same time as Edith Durham (1863-1944), a Victorian British traveler and human-right activist, and Franz von Nopcsa (1877-1933), a Hungarian nobleman and secret agent of the Habsburg Empire. All of them belonged to the founding generation of Albanian studies and regarded the local customary laws, based on blood relations, as the very essence of Albanian Volksgeist, even though very different genres are represented in the works that resulted from their documentation (Doja, 2011). Durham and Nopcsa left a series of travel writings of genuine value to posterity, whereas Gjeçov provided a remarkably competent piece of work wherein customary social institutions are described with textbook precision (Gjeçov, 1933/1993). 
In the aftermath of the First World War, German Völkerkunde never recovered from what led to the loss of the German colonies, destroyed the funding sources of German scholarship, and eradicated the international networks German scholars had built up over the previous four decades (Penny and Bunzl, 2003). Similarly, although Austrian Volkskunde claimed scholarly hegemony in the Balkans, the demise of the Dual Monarchy with First World War can be seen as the demise of the regional scope of Austrian scholarship that was compromised by a new political order (Gruber, 1998). The fate of professional institutions such as the BalkanAbteilung of the Museum für österreichische Volkskunde that became a relic of a bygone imperial past (Marchetti, 2013) is indicative of what was left of the great Danube Monarchy, politically unstable, suddenly of marginal international influence, and without any of the pomp of empire. Austrian interests in the Balkans, including Albania, lost priority due to differing geopolitical contexts and reshaping of the state's character and size, but never totally broke down, however. Albania became then a refuge where one could escape the sad realities of interwar Vienna and Weimar Germany. No longer the victim of a Byronian fantasy of an untamed wildness, interwar Albania emerged as a projection screen for nostalgic fantasies of any number of disaffected Europeans, a miniature of either a great European past, or of a grand European future (Hemming, 2012). Not surprisingly, the interest in Albania shifted from pure exoticism and acquired an expansionist political character.

During the Nazi rule, both Völkerkunde and Volkskunde went through an institutional integration into the Third Reich that was instigated from above but simultaneously found support from and was complemented by certain continuities in the public sphere where an adventurist and voyeurist exoticism of "primitive peoples" (Naturvölkern) and "people's cultures" (Volkskulturen) continued to prevail. In addition, the expansionist political and military plans of Nazi Germany's leaders definitely included a number of scenarios and plans for Germany to become again a colonial power outside Europe, which were the rationale behind serious material efforts that Nazi Germany mobilized for colonial research (Mosen, 1991). However, more than anything else, the legacy of German diffusionism from the "civilizing circles" (Kulturkreise) of "civilized peoples" (Kulturvölker) and the huge research projects in race studies of imperial Germany created an established acceptance on which the German racism and genius-centered view of humanity in the first half of the twentieth century could build with their own schemes and projects, and with increasingly murderous ambition, which is especially shown in the practical involvement of both Völkerkunde and Volkskunde in Nazi Germany's colonial and holocaust programme inside Europe. ${ }^{3}$

German interests in the Balkans during this time showed in the area of economic "supplementation" (Ergänzungswirtschaft), i.e. exploitation, within the framework of the Mitteleuropäische Wirtschaftstag, which from 1931 to 1944 was a forum of German leading corporations, banks, and trade associations that initially pursued the goal to win the Central European market economically and indirectly to rule it politically (Thörner, 2008). Among other things, the scientific approach of Südostforschung was meant to prepare and underpin spatial planning which 
included the deportation of large portions of diverse populations. In both cases, Austrian expertise also played a considerable role (Promitzer, 2012). It also seems that the ideal-typical descriptions of Albanian customary law, noble masculinity and warrior's honour might have underpinned some German Wehrmacht autobiographies from the time of occupation in Kosovo and Albania (Schmidt-Neke, reported in Schwandner-Sievers, 2008: 57). The contexts of the geopolitical position of the German Reich and the Habsburg Monarchy towards the Balkans in the decades before the First World War and the position of Nazi Germany and Austria towards this region during the Second World War determined the respective activities of scientific research and the respective perceptions of public opinions. Scholars, travelers, adventurers and experts either followed or prepared the multilayered economic and political interests of their respective community.

After the Second World War, the early twentieth-century image of the Albanians was frozen until the end of the century when the country opened again to foreign travelers, like the other East European countries that were discovered as "new exotic lands" in the aftermath of the demise of socialism (Skalnik, 2002). Interestingly, however, the North Albanian mountain territories were exploited from the early to the late twentieth century in very similar ways, open to discoverers and adventurers (Kaser, 2002). Reports of a traditional social structure based on kinship, together with the blood-feud and the archaic customary and legal institutions, have aroused the enthusiasm of many Western scholars and journalists, not necessarily limited to a Germanwriting tradition. It seems that a pervasive continuity in Albanian studies, as elsewhere, is that fiction played an enduring role for both local and foreign scholars, taking literally many issues played out in nonacademic texts. Particularly, a rewriting of customary laws seemed to be the translation in Western languages of the famous Albanian novelist Ismail Kadare's Broken April in the 1990s. ${ }^{4}$ Afterwards, many continue to flock to the highlands of northern Albania in search of what they imagine, again, to be the distilled essence of the mountain spirit, a barbarous and splendid anachronism embodied in a sort of primitive and fearless mountain people living according to an ancient code of honor enforced by "tribal" law on the margins of modern Europe.

Marriage codes, blood feuds, religious beliefs, hospitality, as well as certain peculiar customs such as the "sworn virgins," those women who allegedly still continue to obtain male status by pledging eternal virginity (Young, 2000), or the distorted use of "biography" that is said to have been specifically exemplified during Socialism in Albania (Rapper, 2006), are put under the spotlight and conventionally described by contemporary foreign writers. Their common approach is simply meant to single out exoticized patterns of traditional social structures, not unlike what Edmund Leach once unforgettably denounced as "the butterfly collecting" of older forms of anthropology (Leach, 1961: 2). They still address readers' curiosity with a colorful touch and amusing reflections, peppered with adventure and mishap, discovery, and unexpected encounters. Incidentally they may cross Albanian "wild" landscapes on horseback, in the footsteps of Byron, Edward Lear, and Edith Durham, portraying the "Land of Eagles" or Europe's forgotten country (Hanbury-Tenison, 2009/2013) as a ruthless and archaic society completely untouched by the twenty-first century, 
an unconventional destination, a mysterious and eccentric picture from another era, a land of tribal warriors and fairytales.

In the hard times of post-communist turbulence during the 1990s, many Western commentators are easily willing to believe that Albanians still live by the strict laws of the Kanun, fuelling again the pictures of a Balkan otherness and bolstering the impression that despite all efforts, this part of the world is not able to Europeanize itself. While some try to address the historical and political complexity of related practice and discourse (Resta, 2002; Voell, 2004), showing the "strategic subversion of stereotypes" (Schwandner-Sievers, 2008), others do not hesitate to mount virulent rhetorical attacks of denigration and vilification on the ground of a presumed "irrationality" of a "culture-bounded" people (e.g. Krasztev, 2002; Carver, 1998). Many publications over the last decades have been using overlapping elements of Balkanization and Orientalization over and over again, mixing frozen images up with new elements, like the one about thousands of bunkers which were built in the communist times (Kaser, 2002), or the standard stories of the "land of the Mercedes owners" in Europe (Clayer, 2003).

This kind of writing seems to be a pure construction and an act of ethnocentrism. Prone to what Johannes Fabian calls “allochronism” (Fabian, 1983/2002), the writers created an allochronic discourse according to which the Albanian other never occupies the same historical time as the Western observer. They created a certain stereotype, not only of "a land of the living past" (Durham, 1909/1994: 1), but also a mixture of exoticism and "Balkanism" (Todorova, 1997), partaking in the logic of many "nesting orientalisms" (Bakic-Hayden, 1995), regarding a "terra incognita" (Pandolfi, 2005) on the "margins of Europe" (Herzfeld, 1987), which promoted an image of Albania and the Albanians that approximated almost any people in the world, but never Europeans. The discussion on this topic, opened by Said's Orientalism (1978), has traced the West-East conceptualization of cultural differences to its intellectual roots of eighteenth-century enlightenment (Wolff, 1994). Seriously, the continued strength of such exoticism in Western scholarship is shocking. Already in the 1950s Claude Lévi-Strauss in his Tristes Tropiques $(1955 / 1973)$ had bitterly deplored similar stances in anthropology. To borrow his terms, this literature on Albania would represent another instance of the same mistake of a whole profession in believing that men are not always men, that some are more deserving of interest and attention only because in the midst of Europe, they seem to astonish us by the apparent strangeness of their customs.

The aspects of what is referred to as Western tradition pertain to an entity characterized by inner mechanisms of exclusion and hierarchies. Actually, the racial hierarchy and developmental logic of Western culture has been the foundation of power relations in the last two centuries. In this context, Albanian culture and self-image was very much influenced by a fundamental division between those associated with the civilized world and those associated with a peripheral position within the Western system and having to navigate between the two. Generally, a curious mixture of identification and exoticization has characterized depictions and descriptions of Albania from an external Western point of view. In turn, the foreign 
attitude became crucial from a native point of view, since there was both an unequal power balance and an internalization of external ideas. The outcome culminated in a conflict between the idea of the eternal nation, embedded in Albanian nationalism, and the actual paucity of political sovereignty during much of Albanian history. This meant that the focal point of the constrained nation became an aggressive negotiation of the political supremacy of Western ideas about the validity and free development of what is conceptualized as national culture and heritage.

\section{The national-communist project of the folkloric tradition}

The folkloric tradition of "people's culture" studies that developed in Albania, which is examined in more details elsewhere (Doja, 2014), cannot be separated from the broader political and social context that generated widespread interest in the collection, description, conservation, and often exaltation of one's own national people's culture altogether with the "scientific" ideal of a nation-building discipline. This became part of broader native studies that native scholars, emulating German terminology, prefer referring to as Albanologie, and which are especially linked to the search for national identity in Albania. This is not, however, a specific trait of Albanian studies (Cabanes, 2004) or even Balkan studies (Naumovic, 1998). Much the same as is generally the case with any native studies that are at once advocacy studies, they have been institutionalized in Albania, as elsewhere in Central and East European countries, at a time of national movement and independence. The desire to stand out from neighboring countries and the aggressive promotion of claims to civilizational superiority and antiquity were, and still are, the characterizing features of these studies. If the nation became nominally independent, but at the price of a sometimes-humiliating form of effective dependence, as in the case of Greece (Herzfeld, 2002), such claims are almost always disproportionate to the political standing of the country. In these situations, almost naturally, a science or a group of sciences is needed that could perform tasks of "national" importance to confirm that there really existed a nation, and that in its pretensions to an independent state the nation had a continuity of territorial possession and a historical legality or at least cultural legitimacy.

People's culture studies in Albania generally celebrated a national model that is supposed to be deeply rooted in the past. Their primary mission was to build up national culture by looking to the 'folk' to document the people's culture of the peasants, in the conviction that in their unsullied preindustrial settings one could reveal the nation's essential traits and the original character of people's culture and people's spirit (Volksgeist). Their methodology is based on folkloric data collection in the manner of German Volkskunde, which can be traced back to Herder's perspective on culture (Sundhaussen, 1973) and other German romantic reactions to the universalism underpinning French enlightenment. In all cases, the parallel does not only lie in a shared acceptance of Aryanist theses emanating from the groves of German academe to uncover similar 
august antiquity and cultural dignity, but above all in the fact that these studies inevitably acquired both a methodological descriptivist orientation and a political nationalist attitude. Apart from they typically indulged in citing national sources produced and reproducing each other within the national context only, the main body of sources in these writings usually consisted of classic German scholarship from the mid-nineteenth to the mid-twentieth century only, largely influenced by the culturalist and historicist tradition of the old German kulturhistorische school, to which the Italian missionary historical studies also belong, and a number of classical anthropo-geographical texts of Albanian culture, all of the early twentieth century. The typical canon of Albanian official historiography and folkloric people's culture studies usually referred to international texts only as long as they served the ultimate goal of constructing national specificity, a particularly antiquated view of national culture and teleological view of national history, and a basic value of cultural and social practices congruent with communist morality. Even nowadays, the so-called "Albanologists" support Albanian interests and as a rule are of German or Austrian stock or belong to the German intellectual tradition.

In their efforts to seize the "authentic" traditions of people's culture such as they were supposed to have "really" functioned in a society of official ideology, Albanian scholars like their fellows in other East European countries were devoted to descriptive and factual information, which provided nothing than localized and historicized snippets of primordial materials, suitable for historical archives and folkloric atlases. Much the same as the programme to create the Deutsche Volkskunde Atlas, particularly emphasized during the Nazi period in Germany (Jacobeit in Hann et al., 2005), it was more important to sketch numerous folkloric-ethnographic atlases and gather massive series of oral literature, including artefacts, dresses, habitations, labor tools, utensils, songs, dances, rites, and ceremonials, which could help sustain folklore festivals and fill ethnographic museums in order to adequately perform the cult of the Nation.

The folklorist framework of such approaches can hardly be considered a methodological framework or a disciplinary approach. Often transformed into a passion for local or national cultures, they can exceed simple collecting, conservation, and study approaches. They become practices of cultural manipulation, a kind of "Fake-Lore" or "Folklorismus," the term used to refer to the voluntarist "invention of tradition" (Hobsbawm and Ranger, 1983). They include the performing, staging, and adaptation of any element of a tradition or folklore outside the cultural context in which it was created, often implying changes in form, meaning, and intended goals of actors. As such, this attitude is particularly likely to be entangled with nationalism and totalitarianism. This entanglement can be inadvertent and unintentional. Yet, depending on countries, political regimes, and ideologies, as the specific cultural practice of folklorism in the heydays of Nazi German Volkskunde clearly showed, such a folklorist framework often becomes, deliberately and intentionally, the prey and fuel of political ideologies stemming from nationalistic claims or totalitarian regimes. 
A pervasive continuity of Albanian people's culture studies during Socialism can be shown in their ambiguous relationship with German intellectual traditions. Given a tradition in important areas of Albanian studies such as linguistics and history, which was set by the most influential Albanian scholars who were trained during the interwar period in German-speaking universities (e.g. Eqrem Çabej or Aleks Buda), people's culture studies in Albania as elsewhere in Central and eastern Europe had developed since the beginning by emulating and replicating the theories and methods of German Volkskunde, perhaps in a way that must have also paralleled the development of Boasian anthropology under the influence of the German anthropological tradition (Stocking, 1996). However, while Volkskunde as a whole was obliged after 1945 to break with its own traditions, Albanian studies remained still preoccupied with the Albanian national character and approached people's culture in the same essentialist terms.

During the early decades of socialism in Albania, the Volkskunde tradition of people's culture studies had another seemingly quite different tradition grafted on to it. Under the label of etnografi, people's culture studies in Albania emulated Soviet etnografiya and followed the logic of the latter's development and separation from folkloristika, as in other East European countries (cf. Hann et al., 2005; Valtchinova, 2004). It is possible that an earlier stage of this elaboration is rooted in a common ground to both Russian and German anthropological traditions, as an intimate acquaintance with descriptive and synthesizing reports of Siberia may have already contributed to the theoretical conceptualization of a German equivalent term of Ethnographie in Göttingen since the 1770s, which was originally elaborated as synonymous with Völkerkunde, in analogy to geography and its German counterpart Erdkunde (Gingrich, 2005: 70-71). However, it is more for specific historical reasons that have more to do with the Soviet influence in eastern Europe, rather than with nineteenth-century developments that saw the field of a descriptive ethnography become opposed to the theoretical field of ethnology, that the emulations of Soviet etnografyia in eastern Europe are often rendered in English with an homographic term such as "ethnography," which is often confused with the allophonic term of the method of "ethnography" in anthropology.

In Albania during this period, however, contacts with Soviet scholars were inexistent and no any known Albanian practitioner of people's culture studies was trained in the Soviet Union..$^{5}$ The only joint research project with colleagues from another "brother" country of the socialist camp was one in collaboration with East German scholars investigating folk music in Albania. Nevertheless, when I joined the Institute of People's Culture in 1985 as a young researcher, even though Soviet intellectual influences were definitely outdated, I was told by my older colleagues that one of the best handbooks of people's culture studies that had helped them to complete their training was written by a Soviet scholar named Sergey Tokarev. I was also advised to use him, as a translation of his works into Albanian could be found in the Institute's Archives. This emblematic scholar is better known as in 1951 he was posted to East Germany to teach for some years at 
Humboldt University in East Berlin and Karl Marx University in Leipzig. Altogether with a few re-emigrants and party ideologists, he greatly influenced the radical kind of transformation and promotion of a dogmatically Marxist Ethnographie out of Völkerkunde and Volkskunde under communist rule in East Germany.

Some leading figures of East German Ethnographie now tend to play down the intensity of Soviet links in general and Tokarev's contribution in particular (e.g. Wofgang Jacobeit or Dietrich Treide in Hann et al., 2005). However, for most of Tokarev's German students, the task was the creative application of theory to the particular social and political situation of East Germany (see Noack and Krause in Hann et al., 2005: 30). According to an internal report in the Archives of Humboldt University in Berlin, he must have provided "essential advice for the development of a Marxist Ethnographie," while his lectures that served as an important reference for generations of students were designed exclusively to promote the "sovietisation" of people's culture studies (Heyden in Hann et al., 2005: 306).

Whether the German Volkskunde tradition and the Soviet etnografiya tradition share common intellectual origins and scholarly trajectories, or the latter was grafted upon the former in Albania and perhaps in other East European countries under the direct influence of East German scholars remains open to discussion. Yet, a homology between German Volkskunde and Soviet etnografiya can be posited on the ground of their particular political and geopolitical frameworks in which they functioned. The ways in which in Germany the discipline was distorted and mobilized for reactionary political ends have long been recognized and articulated (Dow and Lixfeld, 1994; Emmerich, 1968; Gerndt, 1987; Lixfeld, 1994). Deeply implicated in racial theories, its practitioners had compromised their scientific integrity to provide scientific support to the fascist ideology and the nationalist and racist policies of the Third Reich. In grave disrepute after 1945, the discipline was obliged to submit itself to a new beginning, which encompassed changes not only in personnel and institutions but also in theoretical orientations. Yet, some incisive analyses show how Volkskunde was deliberately relaunched after 1945 in the East German Zone of Soviet administration later to become the German Democratic Republic (Scholze, 2001).

In Albania as elsewhere, the etnografi studies conceived culture as a core characteristic of a deliberately ethnicized concept of folk (etnokultura), which merged into that of people and nation (kultura popullore-kombëtare), paralleling the concept of "ethnos" in Soviet etnografiya (Bromley and Kozlov, 1989). While the category of "people" (Volk) in kultura popullore slipped easily from connotations of "traditional" and "archaic" into a political equation of "people" with "nation," it was increasingly associated with an additional socio-class understanding of the "people" (Volk) leading to a specific concept of people's culture as the socialist culture of "working people," best elaborated in the socio-class category of "demos," which in East German Volkskunde was distinguished from the more general ethno-cultural category of "ethnos" (Noack and Krause in Hann et al., 2005: 42). Such a refinement in East Germany might have been useful to avoid the 
thorny question of East German nation in the context of a divided Germany (Mohrmann in Hann et al., 2005: 198). Yet, the recognition and accentuation of people's culture as the socialist culture of "working people," namely the oppressed people, who according to Marxist ideology are uncompromisingly opposed to exploitative classes, was also an important consequence of Leninist theory of two exclusively differentiated national cultures in class societies. Researchers were now in charge of a broader perspective on the study of socialist transformations and new ways of life, following the Stalinist concept of building a new Volkskultur to be "national in form and socialist in content" (Zojzi, 1962: 9).

From the initial period of nation-building through socialism, and into the postsocialist period, the most important ideological implication of people's culture studies is that they are intricately linked to national politics. People's culture studies function to explore and construct a particular vision of the self against the other, and facilitate their own subversion as scholarship into a political instrument of propaganda. Within the limited changes and innovations that occurred in the socialist decades in Albania, as in other East and Central European countries, the exclusionist communist project and propaganda did much to transform cultural and historical traditions into instruments for justifying and magnifying the "original," "authentic," and "immutable" people's foundations of the political and ideological regime (Doja, 1998).

As such, the exclusionist socio-class understanding of the "people" in Albania paralleled other types of political folklorism and culturalist projects where specific ethno-religious and ethno-racial categories of the "people" were used in support of both chauvinistically and ideologically charged nationalisms and fascisms. The history of archaeological excavations in interwar Albania, for instance, is shown to put emphasis on the "Romanitá" connected to the historical myths of Italian fascism (Gilkes, 2004). On the Butrint site where Greek myths locate both Aeneas and Andromache, archaeological findings were aimed at proving the Roman presence, which should legitimate the right of fascist Italy in restoring its authority on the eastern shore of the Adriatic, and finally prepare the annexation of Albania in 1939 (Cabanes, 2004). Similar projects of cultural engineering are also illustrated by the ethno-religious ideology underlying the political instrumentality of the Serbian mythology of the Battle of Kosovo in support of the chauvinistic Serbian nationalism from the nineteenth century to the last war over Kosova in the 1990s. While this comparative argument is also made elsewhere (e.g. Gossiaux, 1995) by also acknowledging an earlier variant of my work at that time not yet published (Doja, 1998), another parallel with the Serbian Kosovo mythologies, again suggested by others as well (e.g. Kaser and Halpern, 1998), must foremost be found in the ethno-racial category of the "people" underlying the instrumental project of German Volkskunde in support of Hitler's propaganda campaign of the 1930 s and early 1940 s to promote the sinisterly notorious ethno-racist Nazi ideology.

Generally, no practitioner of people's culture studies and no archaeologist in the communist period remained unaware of the connection their work had with 
political interests, though many may wish to deny it and maintain ideas of academic neutrality (cf. Shanks and Tilley, 1992). Surely, it is unrealistic to think that simply one cannot or should not allow oneself to be part of the political landscape of their own research. It is also inappropriate to say that this is what social scientists should or should not do. Often anthropologists are open to become politically engaged in the problems of the people they are studying. Actually, there is no way that one can do anthropology or social science without taking a political stance. Social scientists are interested more and more in public engagement, while those who insist that one should be political neutral are deceiving themselves at the very best and others as well.

The problem is more seriously in the fact that quite often Albanian scholars have been seeking the support of politics and state administration to secure a comfortable academic position. Not only was this the case for scholars holding high-ranking academic offices and affiliated with the communist party, as had been the case with almost all directors of research institutes at any time during the communist regime (a situation that continues to be so), but also for well-respected scholars, in high esteem for their German education and seemingly not involved in politics (e.g. Aleks Buda or Eqrem Çabej). Albanian historiography developed in communist Albania after 1945, thanks to Genosse Aleks, the venerable Comrade President of the National Academy of Sciences "and his Party" (Schmitt, 2005). Similarly, the development of philology owes much to that other emblematic figure, who in spite of his being actively promoted by Monarchic Albanian, Fascist Italian, and Nazi German regimes alike, and even being offered a minister position in the government of German-occupied Albania (Martucci and Genesin, 2012), had been able to become the unchallenged paradigmatic scholar during the communist regime - reputedly so much intransigent by so many other notorious accounts.

Political and methodological servility among scholars was enforced in many cases during the communist regime, transforming them into totalized subjects with virtually no scientific courage. Many practitioners of people's culture studies would even adopt a very unethical behavior, adjusting their "findings" to the official dogma of communist ideology and propaganda. They indulged in "ethnographically validating" the impact of socialist economic developments and "the great transformations from traditions to modernizations in the ways of life in rural areas" in accordance with the principles of a socialist society, as was the case with many works of the time, still reproduced in recent collections without any revision at all (e.g. Gjergji, 2002).

The new vision of people's democracy as a society without internal struggles required a new ideological model that could create an image of unity and homogeneity. This model was provided by national-socialism or the Stalinist conception of culture that should be "national in form and socialist in content," and which became a slogan directly promoted by the ruling party. The implementation of the national-socialist principles of the folkloric people's culture studies, which must be examined in more details at another time, may be seen as a direct outcome of many people having to be forcibly assimilated into the Albanian cultural norms described 
as "socialist". Otherwise, they have to be expelled, stigmatized as "de-classed" (deklasuar) and "people's foe" (armik i popullit), relegated to "internal exile" (internim), imprisoned or killed.

Arguably, though indirectly, people's culture studies must have mattered in an extreme, sometimes devastating way for many people, by giving legitimacy and laying "theoretical foundations" to policies of class repression, expulsion, and resettlement of "backward" and therefore "alien" people. The practitioners of folklorist studies of people's culture were only too pleased to participate in advancing notions of authenticity and superiority of the socialist people's culture, which often turned them into prestigious bearers of "authority". Internal cultural regimentation, more than anything else, provided them with a firm base to establish a presumed common code of socialist morality, empowering them to consolidate their authority, while people's culture was used as a primary measure and economic coercion as the most compelling instrument of the authoritarian regime. As such, people's culture studies during socialism in Albania and elsewhere, like their counterparts in German Volkskunde, must be unhesitatingly indicted as nationalist and communist apologists for official policies. Unequivocally, Albanian studies of people's culture in the socialist period, based on their conservative national and political objectives, were highly disposed if not even predestined to be used and misused under communist rule as a national science of systemically stabilizing state control. That is why the story must be told of a profession whose proclivities towards national-socialist ideology and conservative thought went along with the communist takeover. Full acknowledgment of this fact can become another instance of the Albanian post-communist willingness to come to terms with the communist past.

In addition, a specific methodological problem emerges in the field of Albanian studies, which concerns as much native people's culture studies as non-native ethnographic accounts and which must be examined in more detail at another time, in taking the way the folkloric descriptions are organized and codified in collected texts as a hardly reasonable but given evidence of life practice. This is especially true, even though seemingly unsuspected, in relation to the class struggle launched against the "backward customs" of certain people. In their rush to obey party directives in adopting a socio-class exclusive understanding of the "people," these studies must have inadvertently paved the way to the much abused considerations of much Albanian history and politics. As a result, many simply believe or deliberately denote that in Albanian society, an important role is played by the archaizing Albanian customary laws, the assumed Albanian clan structures and patriarchal gender relations, or the supposed Albanian religious and regional divides.

Actually, the often violent programmes to modernize whoever people were deemed less culturally or ideologically advanced cannot substantiate the perception and isolation of a rural, tribal, patriarchal, and Catholic North. Rather than traditions that often were said to rely on parallel legitimacy structures or be the source of resistance to the regime, this seems to be an unintended effect of the reifying 
discourse of both state policies and people's culture studies. Along with the reification of the essential Albanian nation and culture which is examined in more detail elsewhere (Doja, 2014), it can be argued that the eager adoption of the communist ideological orientation by people's culture studies as a way to service the evolving ideological claims of the Hoxha regime must have been responsible for the further reification of many other cultural views on Albanian society. In the last analysis, while this argument must be examined in more detail at another time, the methodological and ideological bias of these studies may have reproduced old patterns of cultural particularism and cultural determinism, while unduly undercutting a more important potential to generate more analytical insights into the specificities of Albanian culture, society, and history.

The perspective of German Volkskunde or Soviet etnografiya and their emulations in the Balkans, including Albania, are certainly not anthropological contributions to a tradition of theory and practice in comparative scholarship. The problem is not just that we are dealing with a large gap between folkloric people's culture studies and anthropology, but these are two traditions with clearly opposed origins, philosophies, and epistemologies. The broad contrast between the comparative enquiries carried out by anthropologists in Western Europe and the definition of the folkloric people's culture studies or "native ethnography" in eastern Europe have long been recognized and articulated (Halpern and Hammel, 1969; Hofer, 1968). Both traditions are profoundly political, as George Stocking showed in a well-known discussion of the opposition between anthropologies of "empire-building" and anthropologies of "nation-building" (Stocking, 1982), and both traditions share conceptual roots with either colonialism or nationalism (Stocking, 1991). Surely, the emergence of anthropology into modernity out of its exotic manifestation (Völkerkunde) as part of the colonial project is not to be minimized, but it was tempered by the crisis of self-doubt and a series of selfcritiques during the post-colonial era. Arguably, anthropology is the only social science that has undergone repeatedly a radical degree of self-discipline. However, to definitely overcome "the definitional straitjacket that we inherited from this history which wedged anthropology between nationalism and primitivism" (PinaCabral, 2006: 665), a comparable transformation of both the empire-building and the nation-building strands requires a more serious and additional engagement with the national-communist debates on exclusivism.

Comparatively, soon after 1945 the most urgent task for any practitioner of the discipline in both West and East Germany, for instance, was the coming to terms with the undeniable fact that their discipline was viewed as one of the most associated with the notorious ideology of German National Socialism. Even though the initial developments in the two German states were completely disparate, the reappraisal was gradually undertaken in succeeding years in relation to the Germanspeaking intellectual tradition as a whole, both in its Volkskunde variant (Dow and Lixfeld, 1994; Emmerich, 1968; Gerndt, 1987; Lixfeld, 1994) and in its Völkerkunde variant (Dostal, 1994; Fischer, 1990; Hauschild, 1995; Linimayr, 1994; Schafft, 2004; Streck, 2000). Undoubtedly, it is still important to clearly show how the 
eighteenth-century Romantic legacy became corrupted in a variety of cultural and political ways by twentieth-century professionals who may have legitimated nationalist ideologies and their communist socio-class variations in eastern Europe, including Albania. It is equally important, however, to equally engage with the post-colonial and post-socialist arguments on imperialism and with the ethnocentric and authoritarian discourses on the global politics of knowledge and truth.

\section{Contemporary Ostpolitik of knowledge and truth}

There is by now a lively debate about the current situation in Albanian studies (e.g. Abazi, 2010; Egro, 2007; Cabanes, 2004; Hodges, 2004; Hoti, 2003; Martin, 2006; Schmitt, 2005; Tarifa, 1996). Still, the reasons why they seem simply not ready for the challenge of an engagement with nationalist ideology and its communist socioclass variation are fairly complex and they must be examined at another time. Similarly, whether or not Europäische Ethnologie, which has displaced Ethnographie at Humboldt University in Berlin, is derived to a large extent from long-established historicist trends in Volkskunde and the disciplinary vision developed during the socialist era (see Noack et al. in Hann et al., 2005: 46, 183) is open to discussion. It also seems that many contemporary Western studies deemed to be value-free and more sophisticated may often show similar serious problems of either methodological and theoretical or political and ideological implications, which are by no means limited to a German-speaking tradition. The contexts of the geopolitical position of German-speaking countries towards the Balkans after the political turns of the 1990s in East Europe and their respective activities of scientific research are now determined by a neoliberal context dominated by programs of institutional establishment and the installation of a new public space.

Even before the end of the Communist regimes in East Europe, in the mid1980s, the Austrian politician Erhard Busek addressed historical connections between Vienna and the Balkans. This happened within a general, liberalconservative discourse on Projekt Mitteleuropa, intended to help strengthen various local dissident persons and groups in their endeavor to fight and topple their respective Communist regimes. Such endeavors were supposed to secure Austria, as the core of the former Habsburg Empire, a convenient position as intermediary in the political rollback in East Central Europe (Busek and Brix, 1986). About a decade later, the special coordinator of the Stability Pact for southeastern Europe that was launched by the Western states in the aftermath of the NATO intervention in the Balkans, in his subsequent book on Austria and the Balkans, pleads for specifically refreshing the old links (Busek, 1999).

In the recent decades, a complex network of international political strategies has been set up in most East European countries with the aim of teaching "governance" in conformity with Western European standards of democracy and market economy. Members of the Austrian political and economic elites also advocated various internationally accorded political, economic, and ultimately military interventions in the Balkans. By doing so, new forms of globally organized post-colonial 
and post-socialist topographies of power and expertise are "disguised by discourses of Europeanization, marketization and democratization typical of the globalist transitional rhetoric," as aptly qualified by one anonymous reviewer. As I showed elsewhere in more detail especially in relation to Albania and Kosova (Doja, 2001), located within new transnational regimes, humanitarian organizations, international institutions, and specific segments of local elites, they are transferred into the local political field of power and they operate in networks that spread in the private and public spheres. They are canonized as models of governance that legitimize the right of interference and intervention, the rhetoric of institution building, and a Western, neo-liberal, forced democratization of the Southeast "margins" of Europe. The power they wield is real, superimposed as it is onto bureaucratic procedures and intergovernmental negotiations, transforming itself into a new form of transnational domination. The current collaboration of German, Austrian, and Swiss scholars with Albanian intellectuals can also be usefully framed within this neoliberal context where the EU European presence frames the supra-colonial conditions of knowledge production that determine the perception and the regime of these "trouble spots" on the margins of Europe.

Among other things, they invoke the diverse cultural attractions of a seemingly forgotten region that now, after the end of Communism and the ensuing Yugoslav Wars, has got rid of various ideological obscurations. Such a discourse reiteratively reinstates the region in a spatiotemporal axis as a buffer zone between the West and the rest, associated with a distant past and "exotic" charm as with various "un-European" and not "really modern" elements, while they associate themselves with civilizational progress and a metropolitan center. Much the same as in the imperial past, they see the region as a target area of specific economic and financial interests of a part of the Austrian elites to establish themselves as regional players (Promitzer, 2012). Interestingly, such activities are propagated, legitimized, and embedded within the framework of a common history, namely by underscoring the links of the Habsburg Empire to the Balkans before the First World War, more specifically the Austrian impact on the independence of Albania.

In any case, local intellectual and cultural elites in both Austria and the Balkans, including Albania, are interested in Balkan "culture" and Austrian "aid," respectively, in a way that prevents them to develop a critical understanding of the supracolonial impact (Pandolfi, 2000) of the German and Austrian activism in the Balkans. ${ }^{6}$ Apparently, this relationship is articulated in the iconic guise of aggressively national culture fashioned to suit Western values promoted by German and Austrian models. With a typical self-colonizing attitude (Kiossev, 2011), native scholars educated or established within German academia (e.g. Martin Camaj or Bardhyl Demiraj, the first and the current chair holders of Albanologie at LudwigMaximilian University in Munich) willingly perpetuate the folkloric essentialism of historicist philology. As a result of this crypto-colonial situation (Herzfeld 2002), Albanians are placed on high cultural pedestals but effectively isolated from other, more brutally material and authoritative forms of power, which ultimately exclude them from access to the globally dominant advantages of modernity. 
In addition, much the same as in the second half of nineteenth century and at the beginning of twentieth century when Albanologie was founded almost exclusively by a generation of German-speaking writers, it seems that many contemporary German-speaking scholars are now taking a new lead in a joint effort to repair what they believe are the culturalist mistakes of previous studies or the nationalist presumptions of local scholars. Interestingly, however, in most cases, they take over in their own account the dichotomous way of thinking that is supposed to stem from more traditional Albanian social structures but emphasized during socialism, according to which it is not uncommon for scholars to be classified under the categories of "natives" and "foreigners" or "friends" and "foes."

Western representations of the "other" are normally criticized by anthropologists, but these hegemonic classifications and a kind of arrogant "exoticizing" and "patronizing" continues even today with some scholars who live in the West and work in the post-socialist East. Frankly, while long-lasting paradigm shifts and actual practices triggered by the transnationalization of scholarship are ignored, a hierarchical order of scholars replicates Cold War stereotypes and supra-colonial patterns of knowledge production, as it is shown in similar Central East European contexts (Buchowski, 2012; Skalnik, 2002). Here, we may also consider the lasting effects of a similarly "exoticizing" and "patronizing" Mediterranean ethnology worked out mainly by Western anthropologists, who are heavily criticized for ignoring local scholars, especially in the case of Greece (Gefou-Madianou, 1993). One may also be reminded of British anthropologists who worked outside Europe and who belatedly realized that they were or were seen as part and parcel of colonialism and imperialism (Asad, 1973; Stocking, 1991). Still, like their Central and East European counterparts, proficient Albanian-born scholars are often disregarded simply because it seems presumptuous from scholars of some localized and otherized stock to make any actual point in the reserved "international theories," as if they could at best nothing but add exegeses and footnotes to "foreign" theorizing.

A case in point is a Vienna meeting sponsored by the Austrian Academy of Sciences where mainly German and Austrian scholars gathered together with only "scholars who do not originate themselves from the region" (Schmitt and Frantz, 2009). Their goal was "to create a solid basis for a future comprehensive discussion with Albanian scholars." It was not clear whatsoever why "a look from the outside is deliberately chosen" that should "exclude Albanian scholars" from such meetings. Actually, it was "to be hoped that such a chosen look from the outside would have the advantage of avoiding the emotional debate and the significant politicization of history and culture in current Albanian studies." But it was not clear why the exclusive fact of a German stock in the pedigree of scholars, for instance a Schwyzer-Tütschman or Viennese coxcomb, should be better situated than other scholars to "contribute to professional and fact-oriented scientific discussions" (Schmitt and Frantz, 2009: 9).

When it comes to scholars who are perhaps difficult to qualify as either "native" or "foreign" because of their being both Albanian-born and proficient in Western 
academia, it seems that their proportion of Albanian stock might induce some of the German-speaking associates to indulge in misinterpretation of arguments behind a cloudy "international theory discourse" to which Albanian scholars must be taught (e.g. Schwandner-Sievers in Schmitt and Frantz, 2009: 173-186). ${ }^{7}$ Else, they may even deliberately close the eyes to certain contributions even though this must have been quite relevant to the topic at hand (e.g. Clayer in Schmitt and Frantz, 2009: 107-130). ${ }^{8}$ Not incidentally, however, for lack of a better engagement with scholarly debates, many of them only rely on whoever paranoiac and hangeron pseudo-scholars in Albania, who are nothing but the by-product of "the social life of projects" and "the western models of civil society" imported to Albania (Sampson, 1996). The greatest merit of some of them (e.g. Ardian Klosi and Fatos Lubonja) is their notorious affiliation to the former regime. ${ }^{9}$ Some others are better known in vernacular Albanian as dumbabist, with reference to the 1914 rural rebellion that shortly after Albanian independence claimed the return to "Father Sultan" of the Ottoman Empire, but which can be freely extended to the former as to all charlatans in need of whichever patronal support in post-socialist postcolonial Albania. Their misuse and abuse of out-of-context theoretical concepts and their seemingly nonconformist media stunts and diatribes are taken at face value, sponsored as a rule by Western public funding, simply because certain Western individual scholars may often take over from them in the mass media and Internet forums to legitimize their own prejudiced positions and buttress their own academic careers at home.

Regarding the nationalist and essentialist presumptions of local scholars, the methods and results of Albanian research related to the issue of Albanian ethnogenesis have already been subjected to a detailed critique by German scholars (Tönnes, 1980). However, preoccupied as they are with identifying the "correct" Albanian old language and history, not unlike previous research, contemporary German-speaking writers still end up with a similar search for origins (e.g.Matzinger, 2009; Schramm, 1999), which cannot bring by any means the irrefutable evidence necessary to make justice to supporters of one or the opposite thesis at hand. Whether hazy hypotheses or revealed truth, they may start the discussion anew, but with old and new arguments that are already condemned for their use and abuse against Albanian and pro Slavic nationalistic purposes (Gostentschnigg, 2006). Ultimately, such endless search for origins seems unable to move away from the useless obsession with the problem of ethnogenesis. While they notoriously introduce something as a protohistoric concept of Albanians being descended from "Proto-Albanians" (Matzinger, 2009), just as more or less man descended from monkey, unfortunately they remain far away from historically approaching dynamic and political processes within actual groups and communities.

More serious is, however, the explanatory framework and the way in which the intricacies and motivations behind much of Albanian history are dealt. A case in point is a book against the autochthony and Illyrian character of the Albanians, trying to prove their immigration from the Central Balkans into their current Western settlements probably at the beginning of ninth century (Schramm, 
1999). The new hypotheses are characterized by a careful historical evaluation of philological sources, especially the borrowed toponyms shedding light on the periods of Late Antiquity and early Middle Ages for which there are only a few sources. Yet, as also acknowledged by young German-speaking scholars, the systematic use of qualifications such as "barbaric language" or "barbarous tribes" that permeate the whole book, meaning everything non-Roman, non-Greek, or non-Slavic, seem inconsiderate for a historian of the end of twentieth century and may at least make any reader feel uncomfortable. Actually, as stated by Gostentschnigg (2006: 59), after a thorough reading of this certainly interesting but in many parts almost adventurous book, one is tempted to return to the author the condescending criticism of emotional approach that he arrogantly makes of local scholars.

Contemporary German-speaking writers may be eager to claim a "neutral approach to the origin of Albanians and Albanian language with the help of a historical linguistics that is only committed to linguistic data and independent of any political motivation" (Matzinger, 2009: 35). They are much at pain, however, to stress "the importance that from linguistic findings no territorial claims whatsoever must be derived in the present." They are actually anxious to stress that "historical linguistics interprets with its traditional methodology each language data in a neutral way and regardless of national political sensitivities," or else "the politicization of these findings from both ethical and scientific points of view is in all respects inappropriate and inadmissible" (Matzinger, 2009: 35). More than anything else, however, such a discourse sounds likely to reproduce the demagogic authoritarian discourse that was practiced during national-socialism and communism by both political leaders and their acolyte scholars.

Similarly, in spite of the author's claim to pay more attention to a Balkan-wide dimension that must not incorporate modern ethno-national schemes, a recent monograph on Skanderbeg (Schmitt, 2009) does the best to show exactly how large Skanderbeg's non-Albanian stock was, just as not incidentally the same author and his associates consider still important the ethnic stock of scholarship (Schmitt and Frantz, 2009). Surely, the author is not so much to blame because he dismisses and demystifies the Albanian national character of the fifteenth-century hero as many Albanians believe. ${ }^{10}$ On the contrary, they should be proud of such a rendering of their national hero as the "New Great Alexander of the Balkans."11 But this should not be a compliment for a scholarly work. More seriously, indeed, the explanatory framework of the author seems to be flawed in his misreading of some forged documents, when the author takes the report of Italian diplomats as if these were the actual words of Skanderbeg's envoy to Pope Nicholas V in January 1454. Actually, in a rather typical style of diplomatic reporting, the diplomats clearly mix the facts with their own interpretation of the facts, and such a misreading must be either deliberate or otherwise inconceivable at the hand of a twentiethcentury historian. ${ }^{12} \mathrm{He}$ nevertheless managed to project common modern Orientalizing and Balkanizing stereotypes of the purported Albanian tribal laws, blood feuds, and the like into his picturing of a fifteenth-century character, not 
unlike the old generation of Austrian and German writers who typically aimed at sensational discoveries to acquire artificial prestige. If this is the case, he would better try Skanderbeg for a homosexual, as this might have been much hipper nowadays, might not it?

A related problem may be a definite moral-ideological position and orientation on Albanian rustic patriarchy, which is very much in line with the Western academic "good citizens" for whom "patriarchy" is the ideological bogey-man just as communism and nationalism are for the neo-liberal free-marketers and multiethnics. In this context, the study of family structures is of relevant importance, though less developed in anthropology than history, where a number of historical works have widely explored western European family and household structures or the transmission of familial property through generations in its consequences on social structure and economic development. They also address questions of kinship structures, the composition of traditional complex families and the principles of household formation in southeastern Europe. In particular, contemporary German and Austrian historical studies have developed in the recent decades a strong historical research specialization, especially at the universities in Vienna and Graz, and produced a series of publications on the Albanian and wider Southeast European kinship structures or family systems in European comparative perspective (see Kaser et al., 2003).

Unfortunately, some of them still reproduce old patterns of cultural particularism and cultural determinism as they seem to not have been totally liberated from the old culturalist legacy of the Kulturhistorische tradition from which official national-communist scholarship emerged in Albania and in the Balkans. Well versed as they are in using the empirical evidence from a wide range of sources, as I showed elsewhere in more detail (Doja, 2010b), they endlessly try to divide and typify cultural areas in Europe and in the Balkans, reminiscent of the anthropo-geographical Kulturkreislehre of the old Vienna school. ${ }^{13}$ These typologies proceed along the lines of purely demographic criteria confined to the evaluation of quantitative data. In doing so, they typically bring back the common approach of "butterfly collecting" that was once unforgettably denounced by Edmund Leach for older forms of anthropology (Leach, 1961). Whatever may be the criteria of simplification used - taken as a rule from characteristics that can be found in sources such as birth, marriage and death registers or census lists, any of such typologies is stereotypically meant to single out exoticized patterns of traditional social structures.

Arguably, this kind of evidence becomes flawed when it is forwarded in support of a position that assumes, for instance, a so-called "Balkan family pattern," which is supposed to be characterized by equal partible inheritance and a multiple-generational household cycle rather than an individual life-cycle. In addition, while in a northern variant scarcity of land and high population density seem to be the decisive factors, the southern variant turns out to be characterized exclusively by a distinctive patriarchal cultural background, where institutional factors and ideological elaborations have got muddled up in what some Austrian scholar blatantly reifies as "Balkan patriarchy" 
(Kaser, 1992, 2008). Not surprisingly therefore, all this becomes good to characterize these peoples as usual, that is, caught up into their agnatic dyadic relationships or their supposed "tribal" organization and "tribal" laws, including not only complex family structures and especially many children, but also predatory warfare, blood feuds, honor killings, birth customs and ancestor worship, cradle betrothal and bride purchase, and other "savage" customs of the like.

Similarly, the cultural myths and ideologies associated with patrilineality are conflated with the actual practices of patriarchy and it is too easily assumed that the patriarchal language and discourses that symbolically support patrilineality result uniformly in outcomes and practices that are simply reified as patriarchal (e.g. Kaser, 2008). As a result, a purely ideological dimension is commonly obscured. On the one hand, a more careful reading and systematic critical analysis of demographic data, historical sources, and ethnographic evidence carried out elsewhere (Doja, 2010b) clearly show that the Albanian family has been confronted for a long time with particularly low fertility rates and with a relatively high average age at marriage for women. On the other hand, a more experiential understanding of ethnographic evidence (Doja, 2013a) makes us aware that social behavior related to sex selection at birth or ways of expressing labour pain at childbirth (Doja, 2005a) can be another indirect indication of women's agency to reassert their role in reproduction and work around traditionalist frameworks of patriarchal ideology. Actually, both Albanian women and men are more likely to prefer sons but both are also likely to try for a daughter especially after a son, or they may be even likely to say that their female child was preferred. This is true despite their apparent overwhelming preference for a son, despite women's relative lack of autonomy in reproductive decisions, despite the fact that women rarely report challenging their husband's decisions, and despite the fact that they rarely report agreeing with their situation in the family and society. In turn, the cultural pressure aimed at limiting Albanian women to their childbearing function, more than anything else allows us to account for the structural, historical, and political conditions in which social behavior takes place. The myth of many children within the so-called clan structures of the supposed patriarchal Albanian family is commonly constructed and conveyed in academic writings, the media, and stereotyped opinions. I showed, however, how the ideological construction of this myth can be invalidated, if we take what is put forward as empirical evidence to be nothing more than a strong cultural activism where women are subjugated to the reproduction of the social group.

Seriously, after the "writing culture" debate (Clifford and Marcus, 1986) and the declaration of war against "reification" and "essentialism," we have become even less able to address that dimension of human life on which anthropologists used to claim some expertise, namely the normative, non-rational, yet intrinsically meaningful aspect of social life we still label "culture." In our eagerness to deconstruct whatever entities were formerly considered to be "out there" and to highlight process and agency over structure and culture, we have contributed to making it intellectually and politically contentious to talk intelligently about differences that 
very tangibly affect people's lives. To account for the structural, historical, and political conditions in which social behavior takes place is not to offer a blanket condemnation of a given culture. Acknowledging the cultural dimensions of human acts and motives need not imply a simplistic understanding of "culture" that reduces all members of a community to social beings who "have a culture" and are "culturally determined" in their individual experiences and their personal aspirations, nor that they are pre-programmed to react in the same manner.

\section{Conclusion}

The specific essentializing discourses that characterize Albanian studies of "people's culture" before, during, and after socialism, altogether with the patronizing attitude of Western scholarship of which the imperial aspiration of Germanspeaking Albanologie can be taken as an illustrative example, may appear unusual and difficult to grasp, if one schematically employs traditional categories developed in current scholarship dealing with this question within a simple historicist perspective. In turn, an articulate analysis of the main intellectual traditions and their impact, linked to a careful examination of the historical contextualization in ideological perspective, is likely to produce a more sophisticated understanding of the German Kulturpolitik of Albanologie and the cultural particularism of Albanian studies. While analyzing the historical, cultural, and political terrain in which certain influential ideas and practices in Albanian studies of people's culture emerged, the aim of this article was to frame the argument in such a way as to focus on a critical reassessment of different strands of scholarship and to take into account the close association of the development of Albanian studies with the imperial colonial, national communist, and post-socialist post-colonial context and ideology.

In methodological terms, I tried to engage with a comparative analysis of ideas and practices rather than with a search for positive literal proof. The presentist approach and critical interest advocated here might not be exhaustive, and certainly a number of questions that remain open will require complementary historicist and historiographic efforts. My presentist and critical approach definitely is positioned and selective. However, if this article has managed to provoke at the very least a non-stereotyped discussion throughout a set of reflections on Albanian cultural particularism and German-speaking scholarship in its association with the emergence and development of Albanian studies, it merely offers to be one among several possible alternatives. I hope it will encourage further debate, deeper enquiries, and thorough reflection, which can suggest different explanations. Even though it might perhaps justifiably attract attention to self-criticism, it may hopefully stimulate and enrich a debate that could much contribute to the already critical research on historical and current Europeanization. Ultimately, while the difficulty of simultaneously taking into account distinct strands of academic traditions is clearly realized, I believe that the attempt to articulate them in relation to one another may lead to a fascinating intellectual problem. The conceptual aspects of this situation not only show how to deal with an extant social structural problem 
of knowledge production but may also have important theoretical and methodological implications beyond those of the specific problems addressed in this article.

\section{Acknowledgements}

I benefitted greatly from the presentations, discussions, comments, and encouragements of all participants, as well as from numerous friends and colleagues who have read parts of this paper at various stages and have helped to improve my argument: Enika Abazi, Chris Hann, Christian Giordano, Andre Gingrich, Sevasti Trubeta, Kurt Gostentschnigg, Stephane Voell, Christian Promitzer, Alexandar Boskovic, Christian Voss, Ioannis Zelepos, Klaus Roth. I am also very grateful to the anonymous reviewers for their insightful comments and recommendations.

\section{Notes}

1. Different parts of this paper were first presented to the conference on "Mainstream and Dissident Scientific Networks between the Balkans and Germany," Humboldt University Berlin, 20-22 September 2012 (Video at http://youtu.be/jLZgUQ1BSjE), to the conference on "The Rise of Anthropology in the Margins of Europe, 1945-1991," Max Planck Institute for Social Anthropology, Halle/Saale (Germany), 9-10 March 2011 (Video at http://youtu.be/NeQ1ECIQSRc), and to the Seminar for Social Anthropology, University of Fribourg (Switzerland), 26 March 2013.

2. Published in a special issue of Ethnologia Balkanica: Journal for Southeast European Anthropology, vol. 2, 1998.

3. A number of studies have shown by now that some of the representatives of Völkerkunde carried out applied research for Nazi purposes, which would benefit from the Nazi killing machine or contribute to it (Dostal, 1994; Fischer, 1990; Hauschild, 1995; Linimayr, 1994; Schafft, 2004; Streck, 2000), while many representatives of Volkskunde produced explicit propaganda for the Nazi regime and elaborated its ideology by using and abusing their academic and professional authority (Dow and Lixfeld, 1994; Emmerich, 1968; Gerndt, 1987; Lixfeld, 1994).

4. Ismail Kadare, Avril brisé, Paris: Fayard, 1982; Broken April, New York: New Amsterdam Books, 1990; Der zerrissene April, Zurich: Ammann, 2001.

5. Alfred Uçi, the first Director of the Institute of People's Culture from 1979 to 1988, was trained in the Soviet Union and he had made one of the most significant and original contributions to people's culture studies in Albania. But he came to the field at a time when any Soviet intellectual influence was to be considered as outdated and, as he admits, he came to this position "in unforeseen circumstances and against his will”" (Uçi, 2007: 5), always considering himself as external to the discipline, keeping with his main speciality in philosophy and aesthetics.

6. This can be shown, for example, by the organization and the proceedings of a spate of joint conferences celebrating the Austrian impact in Albanian scholarship and statebuilding, in May 2012 in Shkodra and in October 2012 in Tirana, or more specifically focused on the celebration of German Albanologie as a model for the contemporary development of Albanian scholarship, in November 2010 and then again in October 2013 in Tirana. Not surprisingly, the critical approach of a few young Austrian scholars is blindly ignored, even though by chance their papers may be given at the very same conferences (e.g. Gostentschnigg in Marashi and Rakipi, 2013: 39-47). 
7. Stephanie Schwandner-Sievers, seems not to have been yet liberated from the ethnocentric bias of considering that some paths can be only beaten by some scholars rather than others, or be the appanage of Western stock. In her rush to display her cherished "international" slant on the history of ideas and theories, oddly enough, she can only play the old "lit-crit" "post-crit" fiddle of deconstructionism. Eventually, she ends up by failing to correctly understand the current theoretical and epistemological debates in general anthropology, in which some other scholars may have been engaged. (For more details on the poststructuralist debate, see Doja (2006b; 2006c, 2007); on Lévi-Strauss's actual theoretical and epistemological contribution to general knowledge, see Doja (2005b, 2006a, 2008a); on the relatedly debated cultural ideologies of ethnocentrism, nationalism, essentialism and fundamentalism, or pluralism, neo-liberalism, post-modernism, relativism, humanism, and universalism, see Doja (2008b, 2010a, 2013a)).

8. Nathalie Clayer is an unsophisticated writer. Her only merit, is perhaps her partnership with some notorious brand of Serbian ultra-nationalist scholarship, which might have provided her with some dubious familiarity with Balkan issues, including Albania. Actually, her claims are stubborn in showing the exclusive Muslim "Other" in the Balkans, like the exclusive "birth of a nation of Muslim majority in Europe" (Clayer 2007). Not only are these claims based on a deliberate use of selective data and an outright exaggerated point of her own, but they also essentialize and reify the otherization of some given nation, and ultimately work for the ideological purpose of civilizational drifts within the Balkans and within Europe itself. (For more details on the instrumentality of religious shifting in the historical reconstruction of identities in multi-religious Albania, see Doja (2000); on the historical development of Bektashism and the political instrumentality of its religious structure within a general ideological cultural system, see Doja (2006d; 2006e, 2006f); on the supposed elective affinities of nineteenth-century Albanian nationalism to religion and specifically to Bektashism, see Doja (2013b) and Abazi and Doja (2013)).

9. They silence the fact that they have been part and parcel of the system that built the very dictatorship of the communist regime to which some among them may have succumbed after having benefited the most, just as they continue to do from today's civil society. They seem not liberated from their persecution complex of hatred and contempt, while more than anything else they continue to grieve for a power lost.

10. The book is published in German only after one full year of media coverage was given to the Albanian translation sponsored by the Swiss Agency for Development and Cooperation which is responsible for Switzerland's overall international coordination of development activities and cooperation with eastern Europe. In so doing, Swiss Embassy in Albania is denounced for sponsoring the humiliation of Albanian national symbols, and hence not only violating international law governing diplomatic activity, but also committing a criminal offense under the provisions of Albanian Criminal Code. At the same time, German Embassy in Albania is also denounced for sponsoring a documentary film as an electoral spot under covert German and Austrian funding, where hanger-on pseudo-intellectuals pushed as "the most prominent enlightened intellectuals of the country" are converted into Albanian national symbols. Whether such accusations are grounded or not may be open to discussion, but they compelled the major Swiss newspaper Neue Zürcher Zeitung to plead the cases before German, Austrian and Swiss public opinions in a debate published on 18 March 2009.

11. For 25 years, the Albanians had fought under Skanderbeg's leadership (1443-1468) to resist Ottoman annexation, for which he earned the papal commendation of 
Athleta Christis by Pope Callixtus III (1455-1458) and was even expected by Pope Pius II (1458-1464) to lead the attempted crusade against the Ottomans in 1464.

12. "In these circumstances came Skanderbeg's envoy to the Pope and said that because of personal hatred against the Turk..." (Schmitt, 2009: 57). Instead, the diplomats write: "Qua è gionto uno cavaliere ambasatore ... di Signor Xanderbech ... e richiede al Papa che lo faza forte de X.M homini e lui li volle metre tuti li suoy subditi in maior numero asay per andare contra el Turcho; e questo non per fede, perchè ancora lui è infidele, ma per hodio privato ha cum el Turcho, lo quale Turcho fece morire lo padre de quel tal Signore e questo tal Signore ha facto morire uno fratello del Turcho..." (Facsimile reproduced in the appendix of the book). Obviously, it is rather naïve to believe that something like the last sentence could have been said by Skanderbeg's envoy to the Pope.

13. As I was giving an earlier version of this paper at the conference on the rise of anthropology in the Southeast "margins of Europe" during socialism, organized in March 2011 by the Max Planck Institute for Social Anthropology in Halle/Saale (Germany), in his discussion following my presentation, Austrian anthropologist Andre Gingrich confirmed my contention by telling us his shock at assessing a similar project submitted for funding to the Austrian Academy of Sciences. He did not disclose the topic or the name of the promoter.

\section{References}

Abazi E (2010) Tranzicioni i munguar në shkencat sociale shqiptare: Deskriptivizmi empirikohistoricist kundrejt qasjes kritiko-analitike [A missed transition in Albanian social sciences: Materialist historicist descriptivism versus critical analytical approaches]. Polis 9: 63-76.

Abazi E and Doja A (2013) Further considerations on the politics of religious discourse: Naim Frashëri and his pantheism in the course of nineteenth-century Albanian nationalism. Middle Eastern Studies 49(6): 859-879.

Asad T (1973) Anthropology and the colonial encounter. London: Ithaca.

Bakic-Hayden M (1995) Nesting orientalisms: the case of former Yugoslavia. Slavic Review 54(4): 917-931.

Bromley Y and Kozlov V (1989) The theory of ethnos and ethnic processes in Soviet social science. Comparative Studies in Society and History 31(3): 425-438.

Buchowski M (2012) Intricate relations between western anthropologists and eastern ethnologists. Focaal: Journal of Global and Historical Anthropology 63(1): 20-38.

Busek E (1999) Os̈sterreich und der Balkan: Vom Umgang mit dem Pulverfass Europas. Wien: Molden.

Busek E and Brix E (1986) Projekt Mitteleuropa. Wien: Ueberreuter.

Cabanes P (2004) Archéologie et identité nationale en Albanie au XXe siècle. Dialogues d'Histoire Ancienne 30(1): 115-122.

Clayer N (2002) God in the Land of the Mercedes: The religious communities in Albania since 1990. Österreischiche Osthefte 17: 277-314.

Carver R (1998) The Accursed Mountains: Journeys in Albania. London: Murray.

Clayer N (2007) Aux origines du nationalisme albanais: La naissance d'une nation majoritairement musulmane en Europe. Paris: Karthala.

Clifford J and Marcus GE (1986) Writing culture: The poetics and politics of ethnography. Berkeley: University of California Press.

Deusch E (2009) Das k.(u.)k. Kultusprotektorat im albanischen Siedlungsgebiet: In seinem kulturellen, politischen und wirtschaftlichen Umfeld. Wien: Böhlau. 
Doja A (1998) Évolution et folklorisation des traditions culturelles. East European Quarterly 32(1): $95-126$.

Doja A (2000) The politics of religion in the reconstruction of identities: The Albanian situation. Critique of Anthropology 20(4): 421-438.

Doja A (2001) Démocratie et stabilité dans le Sud-Est Européen: Facteurs humains, culturels et sociaux. Les Temps Modernes 56: 147-166.

Doja A (2005a) Rethinking the Couvade. Anthropological Quarterly 78(4): 919-951.

Doja A (2005b) The advent of heroic anthropology in the history of ideas. Journal of the History of Ideas 66(4): 633-650.

Doja A (2006a) The shoulders of our giants: Claude Lévi-Strauss and his legacy in current anthropology. Social Science Information 45(1): 79-107.

Doja A (2006b) The kind of writing: Anthropology and the rhetorical reproduction of postmodernism. Critique of Anthropology 26(2): 157-180.

Doja A (2006c) The predicament of heroic anthropology. Anthropology Today 22(3): 18-22.

Doja A (2006d) A political history of Bektashism from Ottoman Anatolia to Contemporary Turkey. Journal of Church and State 48(2): 421-450.

Doja A (2006e) A political history of Bektashism in Albania. Totalitarian Movements and Political Religions 7(1): 83-107.

Doja A (2006f) Spiritual surrender: From companionship to hierarchy in the history of Bektashism. Numen: International Review for the History of Religions 53(2): 448-510.

Doja A (2007) Creative misreading and bricolage writing: A structural appraisal of a poststructuralist debate. Portuguese Review of the History of the Book 11(22): 89-104.

Doja A (2008a) Claude Lévi-Strauss at his centennial: Toward a future anthropology. Theory, Culture \& Society 25(7-8): 321-340.

Doja A (2008b) From neolithic naturalness to tristes tropiques: The emergence of LéviStrauss's new humanism. Theory, Culture \& Society 25(1): 77-100.

Doja A (2010a) Claude Lévi-Strauss (1908-2009): The apotheosis of heroic anthropology. Anthropology Today 26(5): 18-23.

Doja A (2010b) Fertility trends, marriage patterns and savant typologies in Albanian context. Journal of Family History 35(4): 346-367.

Doja A (2011) Customary laws, folk culture, and social lifeworlds: Albanian studies in critical perspective. In: Breneselovic Luka (ed.) Spomenica Valtazara Bogišića o stogodišnjici njegove smrti [Gedächtnisschrift für Valtazar Bogišić zur 100. Wiederkehr seines Todestages], Vol 2. Beograd: Sluzbeni, p. 183-199.

Doja A (2013a) Invitation au terrain: Mémoire personnel de la construction du projet socioanthropologique. Bruxelles: Peter Lang.

Doja A (2013b) The politics of religious dualism: Naim Frashëri and his elective affinity to religion in the course of 19th-century Albanian activism. Social Compass: International Review of Sociology of Religion 60(1): 115-133.

Doja A (2014) From the native point of view: An insider/outsider perspective on folkloric archaism and modern anthropology in Albania. History of the Human Sciences 27: 4.

Dostal W (1994) Silence in the darkness: German ethnology during the National Socialist Period. Social Anthropology: Journal of the European Association of Social Anthropologists 2(3): 251-262.

Dow JR and Lixfeld H (eds) (1994) The Nazification of an academic discipline: Folklore in the Third Reich. Bloomington: Indiana University Press.

Durham E (1909/1994) High Albania. London: Virago, 1994. 
Egro D (2007) Historia dhe ideologjia: Një qasje kritike studimeve osmane në historiografinë moderne shqiptare [History and ideology: A critical approach to Ottoman studies in modern Albanian historiography]. Tirana: Maluka.

Emmerich W (1968) Germanistische Volkstumsideologie: Genese und Kritik der Volksforschung im Dritten Reich. Tübingen: Tübinger Vereinigung für Volkskunde (ger).

Fabian J (1983/2002) Time and the Other: How Anthropology Makes Its Object. New York: Columbia University Press, 2002.

Feichtinger J, Prutsch U and Csáky M (eds) (2003) Habsburg postcolonial: Machtstrukturen und kollektives Gedächtnis. Innsbruck: Studien-Verlag.

Fischer H (1990) Völkerkunde im Nationalsozialismus: Aspekte der Anpassung, Affinität und Behauptung einer wissenschaftichen Disziplin. Berlin: Reimer.

Gefou-Madianou D (1993) Mirroring ourselves through western texts: The limits of an indigenous anthropology. In: Driessen Henk (ed.) The Politics of Ethnographic Reading and Writing: Confrontations of Western and Indigenous Views. Saarbrücken: Breitenbach, pp. 160-181.

Gerndt H (ed.) (1987) Volkskunde und Nationalsozialismus. München: Münchner Vereinigung für Volkskunde, [Cf. Helge Gerndt, "Deutsche Volkskunde und Nationalsozialismus: was haben wir aus der Geschichte gelernt", In: Schweizerisch Archiv für Volkskunde 91 (1995): 53-75].

Gilkes OJ (2004) The Trojans in Epirus [voyage of Aeneas]: archaeology, myth and identity in interwar Albania. In: Galaty Michael L and Watkinson Charles (eds) Archaeology under Dictatorship. New York: Kluwer, pp. 33-54.

Gingrich A (2005) The German-speaking countries - ruptures, schools, and nontraditions: reassessing the history of sociocultural anthropology in Germany. In: Hann CM (ed.) One discipline, four ways: British, German, French, and American anthropology. Chicago, IL: University of Chicago Press, pp. 59-153.

Gjeçov S (1933/1993) Kanuni $i$ Lekë Dukagjinit [Law of Leka Dukagjini]. Shkodra: Shtypshkronja Franceskane, 1993. [Transl. Italian, Roma: Reale Academia 1941; German, in: Zeitschrift für vergleichende Rechtswissenschaft 54-56, 1954-1958; Bilingual AlbanianEnglish, New York: Gjonlekaj Publishing 1989; French, Peja: Dukagjini Books 2001].

Gjergji A (2002) Mënyra e jetesës në shekujt XII-XX [Ways of Life in 12th-20th Centuries]. Tirana: Kotti.

Gossiaux J-F (1995) Le sens et le verbe: sur deux modes opposés d'instrumentalisation politique du folklore. L'Homme: Revue Francaise d'Anthropologie 35(135): 127-134.

Gostentschnigg K (1999) Die Verflechtung von Wissenschaft und Politik am Beispiel der österreichisch-ungarischen Albanologie. Südost-Forschungen: Internationale Zeitschrift für Geschichte, Kultur und Landeskunde Südosteuropas 58: 221-245.

Gostentschnigg K (2006) Die Frage der albanischen Ethnogenese: Ein historischer Abriss ihrer Diskussion bis zum Ende des 20. Jahrhunderts. Grazer Linguistische Studien 66: 39-60.

Gruber S (1998) Austrian contributions to the ethnological knowledge of the Balkans since 1850. Ethnologia Balkanica: Journal for Southeast European Anthropology 2: 209-224.

Haberlandt A (1917) Kulturwissenschaftliche Beiträge zur Volkskunde von Montenegro, Albanien und Serbien: Ergebnisse einer Forschungsreise in den von den k.u.k. Truppen besetzten gebieten, Sommer 1916. Wien: Verein für Österreichische Volkskunde, Zeitschrift für Österreichische Volkskunde, 23.

Halpern JM and Hammel EA (1969) Observations on the intellectual history of ethnology and other social sciences in Yugoslavia. Comparative Studies in Society and History 11(1): $17-26$. 
Hanbury-Tenison R (2009/2013) Land of Eagles: Riding through Europe's forgotten country. London: I.B.Tauris, 2013.

Hann CM and Bošković A (eds) (2014) The Rise of Anthropology 'on the Margins of Europe' 1945-1991. Berlin/Münster: Lit Verlag.

Hann CM, Sarkany M and Skalnik P (eds) (2005) Studying Peoples in the People's Democracies: Socialist Era Anthropology in East-Central Europe. Berlin/Münster: LIT Verlag.

Hauschild T (ed.) (1995) Lebenslust und Fremdenfurcht: Ethnologie im Dritten Reich. Frankfurt: Suhrkamp.

Hemming A (2012) German-speaking travel writers in interwar Albania. In: Hemming A, Kera G and Pandelejmoni E (eds) Albania: Family, society and culture in the 20th century. Münster: Lit, pp. 115-129.

Herzfeld M (1987) Anthropology Through the Looking-glass: Critical Ethnography in the Margins of Europe. Cambridge: Cambridge University Press.

Herzfeld M (2002) The absent presence: Discourses of crypto-colonialism. South Atlantic Quarterly 101(4): 899-926.

Hobsbawm E and Ranger T (eds) (1983) The Invention of Tradition. Cambridge: Cambridge University Press.

Hodges RO (2004) Rejecting reflexivity? Making post-Stalinist archaeology in Albania. In: Brodie N and Hills C (eds) Material Engagements: Studies in Honour of Colin Renfrew. Cambridge: McDonald Institute for Archaeological Research, pp. 145-164.

Hofer T (1968) Anthropologists and native ethnographers in Central European villages: Comparative notes on the professional personality of two disciplines. Current Anthropology 9(4): 311-315.

Hoti I (2003) Në udhëkryqet e historisë dhe të historiografisë shqiptare [On the cross-roads of Albanian history and historiography]. Prishtina: Instituti Historisë.

Johler R, Marchetti C and Scheer M (eds) (2010) Doing anthropology in wartime and war zones: World War I and the cultural sciences in Europe. Bielefeld: transcript.

Kaser K (1992) Hirten, Kämpfer, Stammeshelden: Ursprünge und Gegenwart des Balkanischen Patriarchats. Wien: Böhlau.

Kaser K (2002) Albania: Orientalisation and Balkanisation of a Balkan country - A contribution to a ongoing debate. In: Kressing F and Kaser K (eds) Albania, a Country in Transition: Aspects of Changing Identities in a South-East European Country. BadenBaden: Nomos, pp. 27-38.

Kaser K (2008) Patriarchy after patriarchy: Gender relations in Turkey and in the Balkans, 1500-2000. Berlin/London: Lit.

Kaser K, Gruber S and Pichler R (eds) (2003) Historische Anthropologie im südostlichen Europa: Eine Einführung. Wien: Böhlau.

Kaser K and Halpern JM (1998) Historical myth and the invention of political folklore in contemporary Serbia. The Anthropology of Eastern Europe Review 16(1). Available at: www.depaul.edu/ rrotenbe/aeer/aeer16_1.html

Kiossev A (2011) The self-colonizing metaphor. In: Atlas of Transformation. Available at: http://monumenttotransformation.org/atlas-of-transformation/html/s/self-colonization/ the-self-colonizing-metaphor-alexander-kiossev.html

Krasztev P (2002) The price of amnesia: Interpretations of vendetta in Albania. Journal for Politics, Gender and Culture 1(2): 33-63.

Leach E (1961) Rethinking Anthropology. London: Athlone.

Lévi-Strauss C (1955/1973) Tristes Tropiques, Nouvelle edition. Paris: Plon, 1973. [New English transl. London: Cape, 1973]. 
Linimayr P (1994) Wiener Völkerkunde im Nationalsozialismus: Ansätze zu einer NSWissenschaft. Frankfurt: Peter Lang.

Lixfeld H (1994) In: Dow JR (ed.) Folklore and Fascism: The Reich Institute for German Volkskunde. Bloomington: Indiana University Press.

Marashi A and Rakipi A (eds) (2013) Shqipëri-Austri: Reflektim Historiografik (Proceedings of Scientific Conferences: Shkodra, May 2012, Tirana, October 2012). Tirana: AIIS Press (Botimet Albanologjike).

Marchetti C (2013) Balkanexpedition: Die Kriegserfahrung der österreichischen Volkskunde: Eine historisch-ethnographische Erkundung. Tübingen: Tübinger Vereinigung für Volkskunde.

Martin S (2006) Archaeology at the crossroads: The future of Albania's past. In: Bejko L and Hodges RO (eds) New Directions in Albanian Archaeology. Tirana: ICAA, pp. 367-378.

Martucci D and Genesin M (2012) Gjuha dhe kultura shqipe në veprimtarinë e Qendrës së Studimeve për Shqipërinë (Centro Studi per l'Albania, 1939-1944). In: Ismajli R (ed.) Shqipja dhe gjuhët e Ballkanit - Albanian and Balkan Languages. Prishtina: ASHAK, pp. 595-607.

Matzinger J (2009) Die Albaner als Nachkommen der Illyrer aus der Sicht der historischen Sprachwissenschaft. In: Schmitt OJ and Frantz E (eds) Albanische Geschichte: Stand und Perspektiven der Forschung. München: Oldenbourg, pp. 13-36.

Mihailescu V, Iliev I and Naumović S (eds) (2008) Studying Peoples in the People's Democracies II: Socialist Era Anthropology in South-East Europe. Münster/Berlin: LIT Verlag.

Mommsen WJ (1980) Theories of Imperialism. New York: Random House, [Orig. Imperialismustheorien: Ein Überblick über die neueren Imperialismusinterpretationen Göttingen: Vandenhoeck \& Ruprecht 1977, 1987].

Mosen M (1991) Der koloniale Traum: Angewandte Ethnologie im Nationalsozialismus. Bonn: Holos-Mundus.

Naumović S (1998) Romanticists or Double Insiders? An Essay on the Origins of Ideologised Discourses in Balkan Ethnology. Ethnologia Balkanica: Journal for Southeast European Anthropology 2: 101-120.

Pandolfi M (2000) L'industrie humanitaire, une souveraneté mouvante et supracoloniale: Réflexion sur l'expérience des Balkans. Multitudes 3: 97-105.

Pandolfi M (2005) Albania as terra incognita: Orientalism and the myth of transition in the contemporary Balkans. In: Peressini M and Hadj-Moussa R (eds) The Mediterranean reconsidered: representations, emergences, recompositions. Gatineau. Québec: Canadian Museum of Civilization, pp. 171-183.

Penny HG and Bunzl M (eds) (2003) Worldly Provincialism: German Anthropology in the Age of Empire. Ann Arbor: University of Michigan Press.

Pina-Cabral J (2006) Anthropology challenged: Notes for a debate. Journal of the Royal Anthropological Institute 12(3): 663-673.

Promitzer C (2012) Austria and the Balkans: Exploring the role of travelogues in the construction of an area. In: Heppner H and Promitzer C (eds) Area Studies in a Globalizing World. Münster: Lit, Available at: https://online.uni-graz.at/kfu_online/ wbLDB.detailLeistung?pOrgNr $=$ \&pIdent $\mathrm{Nr}=-48188 \& \mathrm{pLstNr}=284873$

Ramadani F (2010) Kontributi i Austro-Hungarisë për zhvillimin e arsimit dhe të kulturës shqiptare 1900-1912. Tetova (Macedonia): Ars-ZZ.

Rapper GD (2006) La 'biographie': Parenté incontrôlable et souillure politique dans l'Albanie communiste et post-communiste. European Journal of Turkish Studies 4. Available at: http://www.ejts.org/document565.html 
Resta P (2002) Pensare il sangue: La vendetta nella cultura albanese. Roma: Meltemi. Said E (1978) Orientalism. New York: Pantheon.

Sampson S (1996) The social life of projects: Importing civil society to Albania. In: Hann CM and Dunn E (eds) Civil Society: Challenging Western Models. London/New York: Routledge, pp. 122-145.

Schafft GE (2004) From Racism to Genocide: Anthropology in the Third Reich. Urbana: University of Illinois Press.

Schmitt OJ (2005) Genosse Aleks und seine Partei, oder: Zur Politik und Geschichtswissenschaft im kommunistischen Albanien (1945-1991). In: Krzoska M and Maner H-C (eds) Beruf und Berufung: Geschichtswissenschaft und Nationsbildung in Ostmittel- und Südosteuropa im 19. und 20. Jahrhundert. Münster: Lit, pp. 143-166.

Schmitt OJ (2009) Skanderbeg: Der neue Alexander auf dem Balkan. Regensburg: Pustet, [Albanian transl. Tirana: K\&B, 2008].

Schmitt OJ and Frantz E (eds) (2009) Albanische Geschichte: Stand und Perspektiven der Forschung. München: Oldenbourg, [Albanian transl. Tirana: Perpjekja, 2012].

Scholze T (2001) Anmerkungen zur Frühgeschichte des Volkskunde in der sowjetischen Besatzungszone bzw. späteren DDR. In: Scholze T and Scholze-Irrlitz L (eds) Zehn Jahre Gesellschaft für Ethnographie-Europäische Ethnologie in Berlin: Wolfgang Jacobeit zum 80. Geburtstag. Münster: Lit, pp. 149-156.

Schramm G (1999) Anfänge des albanischen Christentums: Die frühe Bekehrung der Bessen und ihre langen Folgen, 2nd. Freiburg im Breisgau: Rombach.

Schwandner-Sievers S (2008) Albanians, Albanianism and the strategic subversion of stereotypes. In: Elwert G, Feuchtwang S and Neubert D (eds) Albanians, Albanianism and the strategic subversion of stereotypes. Anthropological Notebooks 14(2): 47-64.

Shanks M and Tilley CY (1992) Re-constructing Archaeology: Theory and Practice, 2nd. London: Routledge.

Skalnik P (2002) West meets East or rather it finds new exotic lands. In: Skalnik P (ed.) A Post-Communist Millennium: The Struggles for Sociocultural Anthropology in Central and Eastern Europe. Prague: Set Out, pp. 185-195.

Stocking GW (1965) On the limits of 'presentism' and 'historicism' in the historiography of the behavioral sciences. Journal of the History of the Behavioral Sciences 1(3): 211-218.

Stocking GW (1982) Afterword: A view from the center. Ethnos: Journal of Anthropology 47(1-2): 172-186.

Stocking GW (ed.) (1991) Colonial Situations: Essays on the Contextualization of Ethnographic Knowledge. Madison: University of Wisconsin Press, (History of anthropology, 7).

Stocking GW (ed.) (1996) Volksgeist as Method and Ethic: Essays on Boasian Ethnography and the German Anthropological Tradition. Madison: University of Wisconsin Press, (History of anthropology, 8).

Streck B (ed.) (2000) Ethnologie und Nationalsozialismus. Gehren: Escher.

Sundhaussen H (1973) Der Einfluss der Herderschen Ideen auf die Nationsbildung bei den Völkern der Habsburger Monarchie. München: Oldenbourg.

Tarifa F (1996) Neither 'bourgeois' nor 'communist' science: Sociology in communist and post-communist Albania. Communist and Post-Communist Studies 29(1): 103-113.

Thalloczy LV (ed.) (1916) Illyrisch-Albanische Forschungen. München/Leipzig: Duncker \& Humblot.

Thörner K (2008) Der ganze Südosten ist unser Hinterland: Deutsche Südosteuropapläne von 1840 bis 1945. Freiburg im Breisgau: ca-ira-Verlag. 
Todorova M (1997) Imagining the Balkans. New York: Oxford University Press.

Tönnes B (1980) Sonderfall Albanien: Enver Hoxhas eigener Weg und der historischen Ursprünge seiner Ideologie. München: Oldenbourg.

Turda M (2013) In search of racial types: soldiers and the anthropological mapping of the Romanian nation, 1914-44. Patterns of Prejudice 47(1): 1-21.

Uçi A (2007) Estetika e Folklorit [Folklore Aesthetics]. Tirana: Akademia e Shkencave.

Valtchinova G (2004) Folkloristic, ethnography, or anthropology: bulgarian ethnology at the crossroads. Journal of the Society for the Anthropology of Europe 4(2): 2-18.

Voell S (2004) Das nordalbanische Gewohnheitsrecht und seine mündliche Dimension. Marburg: Curupira.

Wolff L (1994) Inventing Eastern Europe: The Map of Civilization on the Mind of the Enlightenment. Stanford: Stanford University Press.

Young A (2000) Women Who Become Men: Albanian Sworn Virgins. Oxford: Berg.

Zimmerman A (2001) Anthropology and Antihumanism in Imperial Germany. Chicago: University of Chicago Press.

Zojzi R (1962) Etnografia shqiptare dhe veprimtaria shkencore e zhvilluar në këtë fushë [Albanian ethnography and the scientific activity in this area]. Etnografia Shqiptare 1: $3-11$.

\section{Author Biography}

Albert Doja is a full University Professor of Sociology and Anthropology at the University of Lille, France, and an Ordinary full Member of the National Academy of Sciences, Albania, holding the first Chair of anthropology. He was awarded with distinction, a PhD in Social Anthropology in 1993 from the École des Hautes Études en Sciences Sociales in Paris and a Professorial accreditation (Habilitation à Diriger des Recherches), in Sociology and Anthropology in 2004 from Paris Descartes University, Sorbonne, qualifying for full University Professorship within French academic system. He has been Honorary Fellow of the Department of Anthropology at University College London, on secondment to the United Nations Development Programme as the founding Vice-Chancellor of the new University of Durres in Albania, and he has held several academic positions in France, Britain, Ireland and Albania, lectured social anthropology and conducted extensive fieldwork research in many other countries. He is on the editorial board of international academic journals and he has so far published a couple of books and many original articles in international peer-reviewed journals (http://www.researcherid.com/rid/C-1637-2008). His special interests include politics of knowledge, power and ideology; politics of culture, religion, language and identity; social and identity structures, discourses, practices, and processes; technologies of the body, personhood, gender construction, kinship and reproduction activism; anthropology of symbolism and intercultural communication, interethnic relations and international migrations; ethnicity and nationalism; cultural heritage and social transformations; anthropology of history; anthropological theory, structural analysis, post-structuralism and neo-structuralism. 